\author{
THE TERM STRUCTURE OF \\ INTEREST RATES AND ITS ROLE \\ IN MONETARY POLICY FOR \\ THE EUROPEAN CENTRAL BANK
}

Arturo Estrella

Frederic S. Mishkin

Working Paper 5279

\author{
NATIONAL BUREAU OF ECONOMIC RESEARCH \\ 1050 Massachusetts Avenue \\ Cambridge, MA 02138 \\ September 1995
}

This paper was prepared for the conference "What Monetary Policy for the European Central Bank?" sponsored by the Centre for Economic Policy Research, Frankfurt, Germany, June 9-10, 1995. We thank Maria Mendez for excellent research assistance. Any opinions expressed are those of the authors, not those of the Federal Reserve Bank of New York or the Federal Reserve System, Columbia University or the National Bureau of Economic Research. The data in this paper will be made free of charge to any researcher who sends us a standard formatted $31 / 2$ " diskette with a stamped, self-addressed mailer. This paper is part of NBER's program in Monetary Economics.

() 1995 by Arturo Estrella and Frederic S. Mishkin. All rights reserved. Short sections of text, not to exceed two paragraphs, may be quoted without explicit permission provided that full credit, including $\odot$ notice, is given to the source. 


\title{
THE TERM STRUCTURE OF \\ INTEREST RATES AND ITS ROLE \\ IN MONETARY POLICY FOR \\ THE EUROPEAN CENTRAL BANK
}

\begin{abstract}
This paper examines the relationship of the term structure of interest rates to monetary policy instruments and to subsequent real activity and inflation in both Europe and the United States. The results show that monetary policy is an important determinant of the term structure spread, but it unlikely to be the only determinant. In addition, there is significant predictive power for both real activity and inflation. The yield curve is thus a simple and accurate measure that should be viewed as one piece of useful information which, along with other information, can be used to help guide European monetary policy.
\end{abstract}

Arturo Estrella

Federal Reserve Bank of New York

33 Liberty Street

New York, NY 100456
Frederic S. Mishkin

Federal Reserve Bank of New York

33 Liberty Street

New York, NY 10045

and NBER 


\section{Introduction}

The term structure of interest rates is mentioned frequently in the context of monetary policy, particularly as an indicator of market expectations or of the stance of policy. Although it is rarely -- if at all -- viewed as a policy target, it is generally conceded to contain some information that may be of use to both market participants and to the monetary authority.

Already a relatively extensive literature has examined the informational and predictive content of the term structure with regard to the conventional final targets of monetary policy, namely inflation and real activity. This paper builds on that literature by examining those relationships in a cross-country framework, and considers the issue of degree of influence that the central bank exercises on movements in the term structure.

Given the nature of the conference, our aim is to consider whether information contained in the term structure of interest rates is potentially useful for the European Central Bank. Hence, we focus primarily on a sample of major European economies (France, Germany, Italy and the United Kingdom). Results for the United States are also presented for reference purposes, especially since much of the previous empirical literature has concentrated on U.S. data. ${ }^{1}$

The analysis begins by looking at the relationship between the immediate instruments of monetary policy and the spread between long- and short-term government interest rates. In the countries considered, a very short-term interest rate (a 'central bank rate') is reasonably characterized as the primary policy instrument. In most cases, there is in fact a 
credit market that is frequently used by the central bank to intervene domestically and over which the bank exerts considerable influence. The use of a short-term rate as the primary policy instrument is by no means a universal principle of monetary policy, either crosssectionally or even in one country over time. Nevertheless, the characterization is not far from reality in most cases, especially at the current time.

Can the central bank control the yield curve spread through this short-term instrument? It can certainly affect the short end of the yield curve to a significant degree. The long end, however, will be determined by many other considerations, including longterm expectations of inflation and real activity. It is therefore much more difficult to find a close empirical relationship between this long rate and the central bank rate. As our results will make clear, the central bank can influence the term structure, but cannot control it in any meaningful sense. Even this weak result, however, suggests that the yield curve may contain useful information about the stance of monetary policy.

The term structure may also contain useful information concerning market expectations of future real activity and inflation. A standard interpretation of the nominal interest rate for a given maturity is that it contains a term corresponding to the ex ante real rate and another term representing expected inflation. Other possible components, such as term or liquidity premiums may make it difficult to isolate the first two elements.

Nevertheless, if real activity is related to real interest rates and if inflation expectations are in any way accurate, the forward looking nominal rate should contain information -- albeit noisy -- about future activity and price movements. 
Furthermore, since the forward looking components should be strongly related to the maturity of the underlying debt instruments, the term structure of interest rates should contain a term structure of expectations regarding future real activity and inflation. Thus, in this paper, we also consider the predictive power of yield curve spreads -- which correspond to forward interest rates -- for real activity and inflation at various future horizons. In both cases, empirical results that have been previously documented for the US economy also seem to hold strongly in European economies as well. The results are consistently significant using various measures of real activity and inflation.

A few generalizations across countries and time periods may be drawn from our analysis.

- An increase in the central bank rate tends to flatten the yield curve, but the yield curve spread tends to fall by less than the increase in the central bank rate. Alternatively, the long rate tends to increase in response to a rise in the central bank rate, but by less than the short rate.

- The extent of the flattening of the yield curve in response to an increase in the central bank rate seems to be related in particular instances to the credibility attached to the central bank move.

- The yield curve spread is a good predictor of future economic activity and the probability of a recession with a lead time of one to two years. The exact lead time depends on the particular measure of activity.

- The out-of-sample performance of the yield curve spread in predicting future recessions has been quite good as compared with other economic indicators. More 
complex models tend to overfit within sample and, consequently, underperform out of sample.

- The yield curve is a good predictor of future inflation with a lead time generally between three and five years.

Notwithstanding these positive empirical results, a compelling case cannot be made for giving the term structure a formal role in monetary policy, such as an intermediate target. The stability of the relationships is not sufficient -- theoretically and empirically -- to warrant such treatment. Nevertheless, there are strong arguments for including the yield curve in monetary policy discussions as a simple and accurate leading indicator of real activity and inflation.

The next three sections present the detailed analysis of the relationship between the term structure spread and (i) the central bank rate, (ii) future real activity, and (iii) future inflation, respectively. A concluding section is followed by a description of the data series used and by an appendix containing further supplementary results. 


\section{Instruments of monetary policy and their effect on the term structure}

\subsection{Statistical results}

We first examine the relationship between the term structure spread and a direct instrument of monetary policy. An efficacious tightening of monetary policy should have differential effects on short- and long-term interest rates. At the short end, the predominant effect is a tightening in the supply of credit, leading to a rise in interest rates. The long end is driven to a much greater extent by changes in expected inflation and in the real ex ante long-term rate. If the tightening is viewed as credible and effective, reduced long-term inflationary expectations should moderate the effect of tighter initial credit conditions. The combined result is that long-term rates tend to rise by less than short-term rates (they could conceivably decline), and the spread between long and short term rates declines. In other words, the yield curve 'flattens'.

Nevertheless, it is also possible that further increases in the short-term interest rate may be expected over a long future period or that current increases are viewed as insufficient to control inflation and drive down inflationary expectations. In either case, the long-term rate may rise as much or more than the short-term rate and spread between the long and the short would therefore not decline. These are the types of phenomena that we explore empirically in this section.

In order to perform the analysis, we must first identify a short-term instrument that serves as an indicator of the stance of monetary policy in each country. There is, of course, 
a long and controversial literature on the appropriate selection and use of monetary instruments. However, our aim here is much more pragmatic: to find an instrument that is clearly under the central bank's control and that is customarily (or simply frequently) used to implement changes in monetary policy stance.

In each of the five countries studied, there is a short-term interest rate that serves these purposes over the observation period. We cover the period from 1973 to early 1995 in the empirical work. These dates are defined somewhat arbitrarily, but correspond to the regime of floating exchange rates and are also to some extent driven by data availability.

In the cases of France, Germany and Italy, we use a very short-term rate on repurchase agreements in which the central bank tends to participate actively. For Germany, this rate had to be supplemented over some short periods by the Lombard rate, as outlined in the section on data description. In the cases of the United Kingdom and the United states, a very short-term rate on interbank claims is used, once again associated with markets in which the two central banks tend to be quite active. We refer to each of these rates in the context of individual countries as 'the central bank rate'.

The activity of the monetary authorities in these markets provides prima facie evidence of their usefulness for present purposes. In addition, research on US monetary policy has found evidence supporting the use of the federal funds rate as an indicator of the policy stance. $^{2}$

The empirical results below are clearly supportive of a relationship along the lines described earlier. Specifically, an unexpected change in the central bank rate leads to a 
flattening in the yield curve for domestic government securities. The extent of the flattening, however, and the explanatory power of the results vary from country to country.

It should be noted that we are essentially examining the relationship between two endogenous variables. In setting the central bank rate, the monetary authority is influenced by past economic indicators as well as by expectations of future economic variables. For these and other reasons, it would be not be appropriate to think of the central bank rate as a purely exogenous variable. To partially deal with the endogeneity problem and to extract the unexpected components or innovations in the variables from the data, we adopt a vector autoregressive (VAR) formulation for the central bank, short- and long-term interest rates. We implicitly adopt a recursive contemporaneous ordering in which the current central bank rate appears in the equations for the short- and long-term rates. Although this formulation does not fully address the endogeneity problem, it provides a parsimonious way of controlling for some of the problematic lagged influences on the contemporaneous endogenous variables of interest.

Thus, let $\mathrm{x}_{\mathrm{t}}$ be a vector whose three components are the contemporaneous end-ofmonth observations for the central bank rate (CB), the 3-month government security rate (BILL) and the 10-year government security rate (BOND). The three equation system may be written as:

$$
x_{t}=B(L) x_{t-1}+U_{t},
$$

where $\mathrm{B}(\mathrm{L})$ denotes a matrix polynomial in the lag operator $\mathrm{L}$. 
Since our focus is on the effect of the central bank rate innovation on the difference between the BOND and BILL rates, the main parameter of interest is $\beta_{0}$ in the following regression:

$$
S P R E A D_{t}=\alpha_{0}+\sum_{i=0}^{6} \beta_{i} C B_{t-i}+\sum_{i=1}^{6} \gamma_{i} B I L L_{t-i}+\sum_{i=1}^{6} \delta_{i} B O N D_{t-i}+\varepsilon_{t},
$$

where SPREAD $=$ BOND-BILL. ${ }^{3}$

The results are presented in Table 1 . As the table shows, the coefficient $\beta_{0}$ is consistently and significantly negative, in line with expectations. The absolute value of the coefficient, however, varies considerably from country to country: the values range from a decline of 20 basis points in the SPREAD for every percentage point rise in the central bank rate in Italy to 90 basis points in France.

Diagnostic tests, such as recursive residuals (see Harvey (1990)), were applied to the regression results for all countries. Only in the United States is there clear evidence of a break in the equation, which occurs after the change in monetary policy operating procedure in October 1979. A Chow test confirmed the break with an $F$ statistic of $F(20,220)=2.16$, which is significant at the $0.4 \%$ level. In the United States, the $\beta_{0}$ coefficient doubled in absolute value from -0.29 before October 1979 to -0.58 thereafter.

Other coefficient estimates in Table 1 provide interesting information. Unconstrained estimates of the sums of the $\gamma s$ and the $\delta s$ suggest that lags of BOND and BILL enter roughly as differences, that is, as lags of the SPREAD. The implicit coefficient of this difference is generally in the 0.8 to 0.9 range, suggesting a moderately high degree of persistence of changes in the SPREAD. 
In each of the countries, the sum of the lagged $\beta$ s is positive, but less than $\beta_{0}$ in absolute value. This suggests that the efficacy of a change in the central bank rate decays over time but does not completely disappear over the six-month lag period. The sum of all the $\beta \mathrm{s}$, including $\beta_{0}$, is about -0.2 in three of the five countries (France, Germany, United States) and in two of those (Germany, United States) it is statistically significant at the 5 percent level.

The fit of the overall results is fairly good, especially for Germany, the United Kingdom and the United States. Nevertheless, the standard errors are high in comparison with the normal moves in the central bank rates in the various countries. In the post-October 1979 United States, for example, an innovation in the central bank rate of 50 basis points would produce on average a decline of 29 basis points in the SPREAD with a standard error of 32 basis points. Thus, although the average direction of the effect is very consistent, results in specific cases are bound to vary considerably. In view of these results, it is hard to argue that the central bank can 'control' the term structure spread with operations at the very short end.

\subsection{Case studies: episodes of monetary tightening in Germany and the United States}

A case study approach may shed some light on factors that affect the relationship between the central bank rate and the term structure spread, but are not easy to incorporate in a statistical model. We take a closer look at the most recent episodes of monetary 
tightening in Germany (1990-91) and in the United States (1994-95). In each case, rises in the central bank rate were clearly identified with monetary tightening and the individual changes in the central bank rate are easy to detect from the data or from explicit central bank announcements.

The case of Germany is illustrated in Chart 1a, which plots daily data for the level of the SPREAD against the level of the Lombard rate. The Lombard rate often signals changes in policy stance and is closely related to the central bank rate, but is not as variable. When the first increase in the Lombard rate came on November 1, 1990, it had been to some extent anticipated by the markets. In fact, the SPREAD had started to decline for about two months prior to the actual change. Nevertheless, the timing and the magnitude of the change were uncertain ex ante. A press report the next day stated that:

The markets, at least domestically, had for some while entertained the possibility of a rate increase. Among other factors, they have seen inflation creeping up... However, market participants were still caught off guard yesterday as the decision in France on Wednesday [October 31] to lower domestic rates by a quarter of a point had appeared to make a German move less likely. ${ }^{4}$

In view of the circumstances, the move contained new information, signalled the central bank's resolve to counter inflation, and most likely inspired credibility. The SPREAD responded by declining further into negative territory. Each subsequent increase in the Lombard rate until December 1991 was followed by further net declines in the SPREAD, although the generally downward trajectory was not monotonic. 
Credibility may have played an important role in the fact that each of the four increases in the Lombard rate was effective in lowering the SPREAD on net. None of the increases were particularly large (three were 50 basis points, one was 25 basis points) and each one of the four contributed to the attainment of the spread's ultimate level. Moreover, each one seemed to contain sufficient information to compel the market to revise long-term inflationary expectations. All in all, a total increase of 175 basis points in the Lombard rate reduced the SPREAD by approximately 225 basis points.

Chart $1 \mathrm{~b}$ presents a similar analysis for the recent tightening in the United States. The target federal funds rate is used as an indicator of changes in the stance of monetary policy. The actual federal funds (CB) rate is allowed to fluctuate significantly on a daily basis and is a noisier indicator. Announcements made by the Federal Reserve at the time of each of the tightening moves make the target rate a reliable public indicator of policy stance. As in the case of Germany, the initial tightening move on February 4, 1994 had been widely discussed by the press and the markets. There remained considerable uncertainty, however, about the timing and the size of the move, especially in view of the scarcity of tangible evidence of increasing inflation. As the chart demonstrates, the first two moves of 25 basis points were followed by a further steepening of the yield curve. After the third 25 basis points increase on April 18, however, the SPREAD started on a generally downward course that was reinforced by each of the subsequent increases in the target central bank rate during the period. In aggregate during the period of tightening (at least so far), a total increase of 300 basis points in the target central bank rate led to a fall of 150 basis points in 
the SPREAD, if measured from the pre-tightening levels, or 200 basis points if measured from the peak levels in late March or early April.

These case studies suggest that a rise in the central bank rate is likely to have a significant effect on the SPREAD if the action is credible and does not create expectations of further moves in the very short term. The central bank rate increase does not necessarily have to be large in order to produce a large effect, as the 25 basis points increase in Germany in August of 1991 demonstrates. A small increase, however, may sometimes create doubts about the central bank's resolve and suggest to the market that further nearterm increases are contemplated, and the usual downward effect on the SPREAD may not ensue.

The above discussion suggests that central bank credibility may also be an important factor in determining the estimated responses of the SPREAD to a change in the central bank rate found in Table 1. As has been pointed out in Huizinga and Mishkin (1986), the period before October 1979 was one in which U.S. monetary policy was accommodative to inflation and so Federal Reserve credibility was low, while after October 1979, monetary policy became nonaccommodative. The switch from an accommodative to a nonaccommodative monetary policy regime is thus one which might be expected to produce a greater response of the SPREAD to a change in the central bank rate. Indeed, this is exactly what we find, with $\beta_{0}$ going from -0.29 to -0.58 from the pre- 1979 to the post- 1979 sample period.

The larger absolute value of the $\beta_{0}$ estimate for Germany relative to the U.S. value in the pre-1979 period, may also be a reflection of higher credibility for German monetary policy. However, the largest absolute value of $\beta_{0}$ found in Table 1 is found for France, a 
country whose monetary policy has in the past not been perceived to be as credible as that of Germany. ${ }^{5}$ These results thus suggest two points. First, we should not expect the response of the term structure SPREAD to changes in the central bank rate to remain the same when there is a change in the monetary policy regime. Second, other factors besides the credibility of monetary policy may be important in determining how the term structure responds to changes in the central bank rate. 


\section{The yield curve as a predictor of future real activity}

\subsection{Predictive power of the yield curve SPREAD}

The significance of the informational content of the term structure in predicting real activity has been documented for the United States in papers by Harvey (1988), Laurent (1988, 1989), Chen (1991), Estrella and Hardouvelis (1991), Bomhoff (1994), Davis and Henry (1994), Davis and Fagan (1994), and Barran et al. (1995). In this section, we apply some of those techniques to the sample of five countries with results that are significant and robust across countries.

Why should such a predictive relationship exist? One possibility -- the 'common factor' explanation -- is that both the term structure and future real activity are determined by current monetary policy. Tight monetary policy would tend both to flatten the yield curve and lead to a slowdown in activity. We have seen already in section 2 , however, that even though the yield curve spread seems to be influenced by current monetary policy, to say that it is determined by it is a gross overstatement.

In addition, if the common factor were the only explanation, the predictive power of the term structure should dissipate when variables representing current policy are added. As seen below, this is generally not the case. It is interesting nevertheless, to examine the significance of the yield curve when alternative monetary variables are added to the predictive equation. The few cases in which the significance of the yield curve spread is 
altered may provide some insights into the features of monetary policy in particular countries.

From a purely theoretical point of view, the yield curve spread may be related positively or negatively to future real output. The common factor explanation suggests a positive relationship, which is typical in previous empirical research. Explanations based on real demand shocks are also consistent with a positive relationship, the flavor of which may be conveyed by thinking of simple future shifts in the IS curve. A more elaborate but suggestive formal model based on the consumption capital asset pricing model is found in Harvey (1988). On the other hand, expectations of future monetary tightening could be associated both with higher interest rates and lower output, especially in the short run, and this could be thought of as future shifts in the LM curve.

The general strategy in this section is to estimate a regression equation in which the contemporaneous value of the SPREAD is used to forecast the change in real economic activity over the following $\mathrm{k}$ periods. The basic equation is

$$
y_{t}^{k}=\alpha_{0}+\alpha_{1} \operatorname{SPREAD_{t}}+\varepsilon_{t},
$$

where $y_{i}^{k}$ is one of various measures of the change in economic activity. It seems natural to include lags of the dependent variable or, more generally, lagged values of quarterly GDP growth in this equation. Empirically, however, such lags are generally insignificant and are omitted from the reported results. The text focuses on a log change in real GDP and on a recession dummy. Results for the log change in industrial production and the change in the unemployment rate are presented in the Appendix. 
In Table 2, the SPREAD is used to predict annualized real GDP growth over the next $\mathrm{k}$ quarters. There is very consistent evidence that the relationship is positive, as previous work for the United States had shown. Furthermore, with the exception of Italy, the results tend to be very significant, especially for horizons of 4 to 8 quarters ahead. In France, Germany and the United States, the significance appears in even shorter horizons and remains for longer ones. In the case of Italy, the results are qualitatively the same, but the statistical significance -- which peaks at the 12 percent level with the 5 quarters ahead equation -- is substantially lower.

Although the statistical significance of the results is fairly consistent across countries, the economic significance varies considerably. For example, in the 6-quarter ahead results, the coefficient varies between 0.35 and 0.62 for the European countries. This means that a one percentage point increase in the SPREAD is associated with average annualized 6-quarter real GDP growth between 35 and 62 basis points higher. The range of the results is almost 2 to 1 . Moreover, in the United States, the coefficient is 1.02 , almost double the highest coefficient in Europe. ${ }^{6}$

Similar results -- both statistical and economic -- are obtained when other measures of real activity are used in place of real GDP. Results using industrial production and unemployment are presented in the appendix (Tables A1 and A2). It may be noted that while the general patterns are the same, details differ for different dependent variables. For example, in contrast to real GDP, the SPREAD is significant in forecasting industrial production in Italy. Other such differences may be noted by comparing Tables 2 , A1 and A2. 
A somewhat different approach involves the prediction of whether or not the economy will be in a recession $\mathrm{k}$ quarters ahead. This type of exercise abstracts from the actual magnitude of economic activity by focusing on the simple binary indicator variable.

Although this forecast is in some sense less precise, the requirements on predictive power are in another sense less demanding and may increase the potential accuracy of the more limited forecast. The limited dependent variables in the analysis below are derived from the timing of recessions by the Center for International Business Cycle Research at Columbia University for the European economies and from the National Bureau of Economic Research for the United States.

Table 3 presents the results of this approach with the SPREAD as the only explanatory variable in a probit regression in which the dependent variable (RECESSION) is a dummy that equals 1 if the economy is in recession four quarters ahead and equals 0 otherwise. Because of the limited dependent variable, the probit regression is nonlinear and has the form

$$
P\left(\text { RECESSION }_{t}=1\right)=F\left(\alpha_{0}+\alpha_{1} \operatorname{SPREAD}_{t-4}\right),
$$

where $\mathrm{F}$ is the normal cumulative distribution function.

Other lead times were considered, but the one-year horizon was generally the most successful and is the only one reported in detail. As was the case with the quantitative dependent variables, the results are generally very good. The estimates are statistically significant, with the exception of France. The economic significance is harder to gauge, since the relationship between the linear combination with which the parameter is associated and the probability of a recession is highly nonlinear. Even though the coefficient is 
constant, the effect of an increase of 1 percentage point in the SPREAD will be very different for different levels of the SPREAD.

The fit of the equation for some countries is striking, particularly for Germany and the United States. Evidence of this is seen in Chart 2, which plots the probability of a recession against shaded regions representing actual recessions, and also in the $\mathrm{R}^{2}$ analogue $\phi$ in Table $3 .^{7}$ Cross-sectionally, it is interesting to note that in contrast to the quantitative equations in which the results are most significant for the United States, in this case it is Germany that has the best fit and also the largest coefficient. These equations were also estimated using monthly recession indices and end-of-month data for the SPREAD. The results, which are reported in Table A3 in the appendix, are very similar.

In Table 3, we also test whether an index of leading indicators, which is available for both the United Kingdom and the United States, contains information useful in predicting recessions that is not contained in the SPREAD. The results show that this is not the case. In the United Kingdom, the leading indicator index has the right sign, but is not significant at the 5 percent level. In the United States, the sign is wrong, although the very low significance level suggests that the coefficient is essentially zero.

\subsection{The role of other monetary policy variables}

Earlier in this section we discussed the possibility that the predictive power of the term structure for real activity may be attributable to the influence of monetary policy on both. We now take a look at whether there is predictive power of the term structure over 
and above that provided by other variables that reflect the stance of monetary policy. We introduce those other monetary policy variables in the equation for predicting future growth in real GDP and examine the significance of both the monetary variable and the SPREAD. The form of the regression equation is

$$
y_{t}^{k}=\alpha_{0}+\alpha_{1} S P R E A D_{t}+\alpha_{2} x_{t}+\varepsilon_{t},
$$

where $x_{t}$ is the contemporaneous measure of monetary policy. In very general terms, the predictive power of the term structure SPREAD remains when other monetary policy variables are introduced. Nevertheless, there are several important exceptions that may be indicative of differences in the structure of the various economies.

In Table 4 we look at the effect of introducing short-term interest rates as proxies for the monetary policy stance. Three such measures are used: the central bank rate (CB) and the bill rate (BILL), which have been defined earlier in the paper, and the real central bank rate (RCB). Because the real central bank rate is an ex ante real interest rate which is not directly observable, the following instrumental variables procedure outlined by McCallum (1976) and Pagan (1984) is needed to estimate this equation. Here the RCB variable included in the regression is calculated as the ex post real rate, that is, as the average nominal central bank rate for a given quarter minus the actual inflation rate from the GDP deflator over the same quarter. The equation is then estimated using instrumental variables with CB, SPREAD, and two lags of quarterly inflation as instruments.

The results are presented in Table 4 in four panels. The first restates the Table 2 results for 4,6 , and 8 quarters ahead, which is where the predictive power was most significant. The next three panels add the $\mathrm{CB}, \mathrm{RCB}$, and BILL variables, respectively, as 
indicated. In general, the SPREAD fares well with the additional variables, but the results have peculiarities in every country that make it useful to review each one in turn.

In France, the significance of the SPREAD remains with all 3 variables, and the central bank rate is also significant. In Germany, $\mathrm{CB}$ and $\mathrm{RCB}$ are not significant, but BILL tends to be so much so that it reduces greatly both the statistical and economic significance of the SPREAD. It appears that a single government interest rate contains more information in Germany than in any of the other countries. ${ }^{8}$ In Italy, the results for the SPREAD alone are not significant, but they become significant when the nominal rates are added. In the United Kingdom, both nominal rates reduce the significance of the SPREAD. A puzzling result is that the RCB increases the statistical and economic significance of the SPREAD, but is itself strongly significant with a positive sign! This may be explained by the fact that there were periods of high inflation (and therefore low RCB) in 1974-75 and 1979-80 that were followed by periods of low real growth. Finally, in the United States, the SPREAD remains highly significant with all three interest rates and none of the latter are significant at these horizons.

In addition to the interest rate proxies of monetary policy, monetary aggregates were used, as reported in Table 5. One-quarter growth in a monetary base (M0), a narrow (M1) and a broad (M2 or M3) monetary aggregate was included for each country. The results are more consistent than they are for the interest rates in that for three countries (France, Germany and the United States) the SPREAD remains significant while neither of the aggregates are. In the United Kingdom, the M1 aggregate is both significant and enhances the significance of the SPREAD. Inclusion of the UK monetary base produces similar 
results, but with an unexpected negative sign for the monetary variable. A slight puzzle here is also Italy, for which the SPREAD becomes significant with the addition of the M1 aggregate, although the aggregate itself is mostly insignificant and has an unexpected sign.

In summary, the term structure SPREAD by itself is useful in predicting real economic activity, especially between 4 and 8 quarters ahead, independently of which measure of activity is used. Moreover, the predictive power does not seem to be attributable solely or primarily to known information about other monetary policy variables.

\subsection{Case study: predicting the last recession in the United States}

Section 3 has focused so far on statistical significance and fit within sample. Some commentators have given the impression that interest rate spread variables did not perform well in predicting the most recent recession in the United States. ${ }^{9}$ To assess this view, we now present a case study of how the yield curve SPREAD performed as a single four-quarter ahead out-of-sample predictor during the last recession, which ran from a peak in the third quarter of 1990 to a trough in the second quarter of 1991 . Following the in-sample results reported earlier, we use the probit regression methodology of Table 3 to forecast out-ofsample four quarters ahead. Specifically, we estimate the probit regression with $\operatorname{SPREAD}_{\mathrm{t} 4}$ as an explanatory variable and data up to quarter $t$, and calculate the fitted value of the probability of a recession in quarter $t+4$ using $\operatorname{SPREAD}_{t}$. The results are presented graphically in Chart 3. 
Comparison of Chart 3 and the US panel in Chart 2 indicates that the in-sample and out-of-sample results are virtually identical. Thus, the substantially higher level of the ex ante probability roughly a year before the recession should have provided a clear signal of the impending real slowdown. It is true that the probability is of the order of about 0.3 , when in prior recessions it had reached much higher levels. Nevertheless, the ex ante probability tends to be very close to zero other than in anticipation of a recession, so that the signal was certainly identifiable. The usefulness of the term structure as a predictor of recessions seems to have held up in the most recent period. 


\section{The yield curve as a predictor of future inflation}

The classic Fisher (1930) equation decomposes a nominal interest rate of a given maturity into a real rate and an inflation expectations component, both for the period from the present to the maturity of the instrument. If expectations are rational, expected inflation will differ from actual inflation by an unpredictable noise term. Combining these two relationships, we obtain that

$$
\pi_{t}^{m}-\pi_{t}^{n}=\alpha_{m, n}+\beta_{m, n}\left[i_{t}^{m}-i_{t}^{n}\right]+\eta_{t}^{m, n},
$$

where $\pi_{t}$ is the inflation rate from $t$ to $t+m$, im is the nominal interest rate from $t$ to $t+m, \alpha$ is the average difference between the corresponding real rates and $\eta$ is composed of the noise terms in the inflation forecasts plus variations of the real rates around their means. ${ }^{10}$ If the real rates were constant, equation (4) suggests that yield curve spreads could be useful in forecasting future changes in inflation. The accuracy of the forecast would depend on the accuracy of the market forecasts of inflation that are built into the Fisher equation. If real rates are not constant, there may still be some predictive power but the results could be noisier or biased.

Mishkin (1990a, 1990b, 1991) and Jorion and Mishkin (1991) have used this framework to examine the predictive power of yield curve spreads in forecasting future changes in inflation. ${ }^{11}$ In summary form, the results indicate that the predictive power is low or nonexistent in the very short term ( $m$ and $n$ within 6 months), but that the accuracy increases as the prediction goes out past 9 or 12 months. In this paper we employ a similar 
underlying methodology, but focus on a longer horizon by using the SPREAD as defined earlier, namely a 10 -year minus a 3 -month interest rate.

With the longer term horizon in the interest rate spread, we adopt a somewhat less formal approach than suggested by equation (4), but one that is consistent with the technique applied in Section 3 to the prediction of real activity. Rather than matching up exactly the maturities of the two interest rates in the SPREAD with the corresponding ex post inflation rates, we use the SPREAD to predict the change in the inflation rate from the last quarter to the next $\mathrm{k}$ quarters. Inflation is measured as the log change in the GDP deflator for each of the five countries. All rates -- interest and inflation -- are expressed in percent per annum. Also, a lagged dependent variable is included in the equation. The latter is not generally significant, except at some of the longer predictive horizons.

The results, summarized in Table 6, are consistent with those of Mishkin (1990a, 1990b, 1991) and Jorion and Mishkin (1991) in that the greatest predictive accuracy is obtained at relatively long horizons, longer than those obtained in predicting real activity. As the table shows, the results for Germany and the United States are very significant even for five years ahead, where the fit peaks in both cases. For Italy and the United Kingdom, there are also some significant results corresponding to somewhat shorter horizons (9 to 12 quarters and 12 to 13 quarters, respectively). Finally, the estimates for France do not exhibit much statistical significance, although the five year horizon comes closest, which in a way is consistent with the German and US results.

Note that in contrast to the corresponding equation for predicting GDP growth, the equation for inflation contains a lagged dependent variable. In the inflation equation, the 
lagged values are sometimes significant. Furthermore, the significance is increased for some countries if one or more single-period lags of inflation are included individually. Nevertheless, the term structure spread remains significant over the relevant predictive horizons even with the inclusion of lagged inflation.

With the exception of Italy, the significance and fit are not as strong in these inflation equations as they are in the equations for real GDP and the other measures of real activity. Nevertheless, there is significance in many cases and the pattern of longer predictive horizons is very consistent. ${ }^{12}$ 


\section{What role for the term structure in the European Central Bank?}

One traditional way of classifying the variables that a central bank examines in the conduct of monetary policy deliberations is to identify them as (i) final targets, (ii) intermediate targets, (iii) indicators of policy stance, or (iv) other economic indicators. Which of these roles is the term structure capable of playing? To be sure, the role of final target is not a realistic option. It is generally acknowledged today that the primary goal of monetary policy, perhaps the only goal, is price stability. Although other interrelated issues may also be important, it is clear that real or potential control of the term structure is in no way a substitute for price stability.

Perhaps somewhat more plausible is a role for the term structure as an intermediate target. However, this would require that the central bank be able to exercise significant control over the term structure and that the term structure in turn bear a stable structural relationship to the future rate of inflation. The empirical work of this paper has established that the term structure is indeed influenced by monetary policy and is related to future inflation and economic activity. Nevertheless, the lack of a clear structural basis for these relationships and the level of uncertainty that remains in the empirical results argue convincingly against the formal use of the term structure as an intermediate target.

It is as an indicator that the term structure may justifiably find a role in monetary policy. In monetary policy deliberations, it is standard procedure to examine a broad range of economic and financial indicators. These indicators may include, for example, the output of large macroeconometric models, simple and direct measures of economic activity such as 
unemployment or inventories, or macrofinancial indicators such as interest rates. In this context, the term structure figures as one more piece of information that, though certainly not decisive, may contain useful supplementary signals.

Clearly, the results in this paper do not support replacing a careful and comprehensive macroeconomic analysis of a large body of data to produce GDP and inflation forecasts with the use of the term structure as an indicator. However, the results here suggest that the term structure can be a useful check on the accuracy of a macroeconomic forecast derived using a broad set of information. For example, if policy analysts produce a forecast which is consistent with the view provided by the term structure, then confidence in the forecast would be increased. On the other hand, if the term structure indicator provided a contrary signal about the course of the economy, then this would send up a flag to the policy analysts that they should scrutinize their forecast further. The term structure indicator would thereby play a valuable role for policymakers at the European Central Bank. 


\section{Conclusions}

This paper has examined the relationship of the term structure of interest rates to monetary policy instruments and to subsequent real activity and inflation in both the United States and Europe. The relationship to policy instruments is one that has not been extensively explored before. The results of this paper show that monetary policy is an important determinant of the term structure spread, but is unlikely to be the only determinant. The relationships to future real activity and inflation have received much more attention in the literature, but much of that work has focused exclusively or primarily on the United States. This paper largely confirms the results of this earlier research in a European context, showing that there is significant predictive power for both real activity and inflation, with horizons of one to two years for the former and longer horizons for the latter.

The literature on predictive power is extended by looking at the joint predictions of the yield curve spread and several monetary policy instruments. In this multiple regression context, looking at real growth one to two years ahead, it is possible to examine which policy instruments contain information similar to that of the yield curve, which contain independent information, and which do not contain much independent information at all (at these horizons). These results vary from country to country and suggest, for example, that 3-month government rates are very important in Germany and that the narrow monetary aggregate is important in the United Kingdom. Nevertheless, in most cases, the term structure is shown to have significant independent information regarding future growth and inflation. 
The evidence provided here suggests, therefore, that the term structure of interest rates does have a useful role as an indicator of the tightness of monetary policy for the European Central Bank. Furthermore, it suggests that the European Central Bank could affect the term structure spread via monetary policy actions on a central bank interest rate. However, our results also indicate that the relationship between monetary policy actions and the term structure spread are unlikely to remain invariant over time. We have seen that changes in the credibility of the central bank are likely to cause this relationship to change and that other factors might affect this relationship. Furthermore, the statistical relationship between the term structure spread and real output and inflation might also change with changes in monetary policy regimes. This would be particularly likely if the European Central Bank decided to target the term structure spread as part of its monetary policy strategy. ${ }^{13}$

Thus, the term structure of interest rates should not be raised to the status of a target. Nevertheless, it can serve as a useful indicator of monetary policy for the European Central Bank. It is a simple and accurate measure that should be viewed as one piece of useful information which, along with other information, can be used to help guide European monetary policy. 


\section{Data definitions, sources, and exact sample periods}

CB

FRANCE Bank of France money market intervention rate, outright purchase of short-term private paper, the "repo rate"; month-end 1973.01-1995.02

GERMANY Lombard rate of the Bundesbank; month-end 1973.01-1982.03

Open market operations of the Bundesbank in security repurchase agreements; month-end 1982.04-1995.02

ITALY Bank of Italy temporary purchase of securities, average rate; month-avg 1982.011995.02. Bank of Italy temporary sales of securities, average rate; month-avg 1981.04-1991.08

Observation uses the average of purchase and sales rate. When only one side was available, the average spread was added/subtracted to the operations during the month.

UK Overnight Sterling interbank deposits; month-end 1977.10-1995.02

June 1980 has a value of 53.95; we used 17.69 , the rate from the day before.

US Effective Fed funds rate; month-end 1973.01-1995.02

BILL Three-month instrument

FRANCE 3-month Paris Interbank offer rate; month-end 1977.12-1995.02

GERMANY 3-month loans; month-end 1973.01-1995.02

ITALY Ordinary Treasury bills, 3-month, gross of tax; month-avg 1974.05-1995.02

UK Treasury bills, 91-day, average allotment rate; month-end 1973.01-1995.01 August 1980 has a value of 0 ; we used 9.6875, the end-of-week rate for the last week of the month.

US 3-month Treasury bill, bond equivalent market yield; month-end 1973.01-1995.02

BOND Long-term government bond rate

FRANCE Public and semi-public sector bonds, secondary market; month-end 1973.01-1995.02

GERMANY Federal public bonds, 10-years, secondary market; month-end 1973.01-1995.02

ITALY Treasury Bonds, net of tax, secondary market; month-avg 1973.01-1995.02 


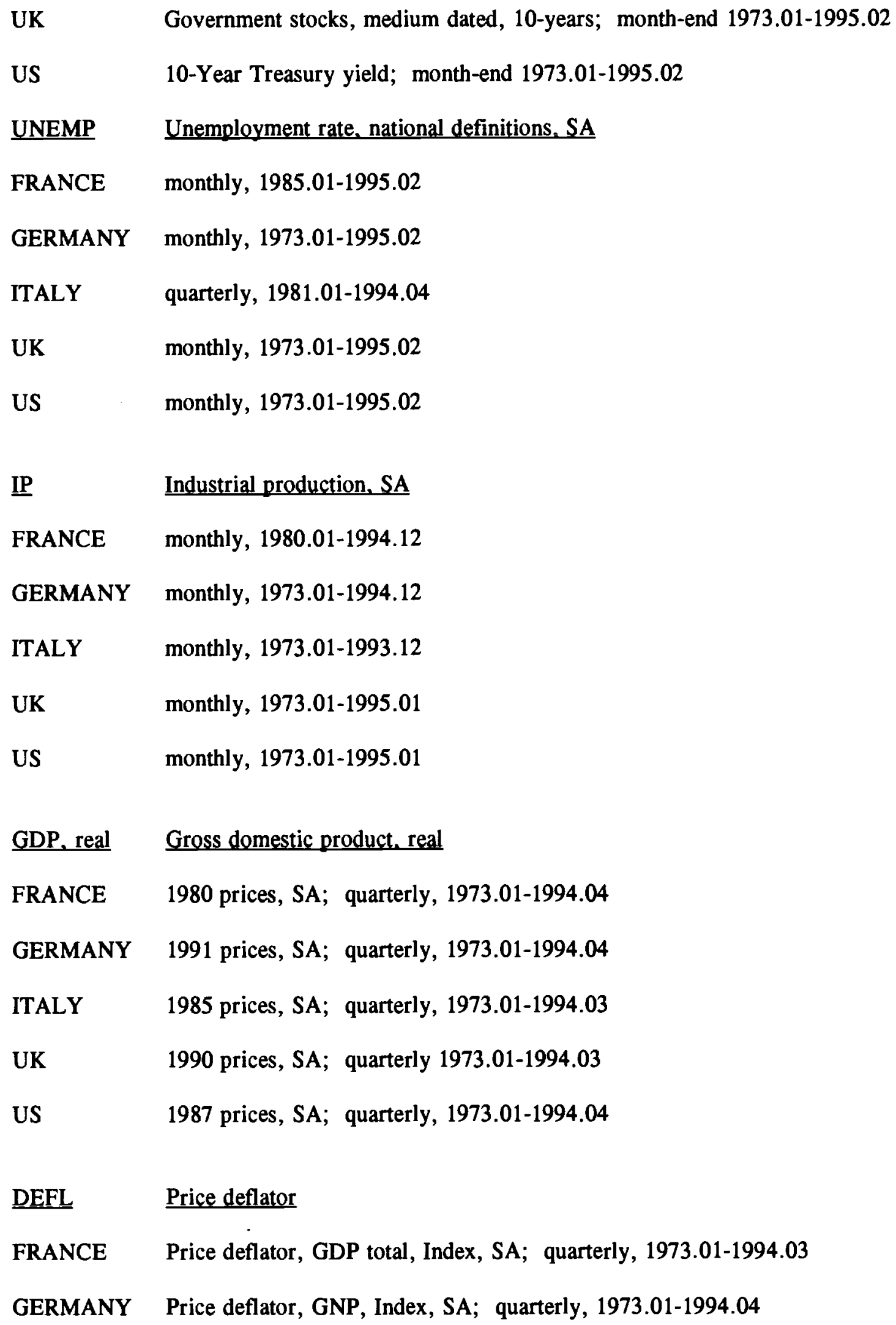


ITALY Price deflator, GDP; quarterly, 1973.01-1994.03

UK Price deflator, GDP; quarterly, 1973.01-1994.03 .

US Price deflator, GDP, SA; quarterly, 1973.01-1994.04

M0 $\quad$ Monetary base

FRANCE Central bank money stock (narrow); NSA; monthly, 1977.12-1994.02

GERMANY Central bank money stock; SA; monthly, 1973.01-1995.02

ITALY NSA; monthly average, 1973.01-1995.02

UK (wide); SA; monthly, 1973.01-1995.02

US SA; monthly, 1973.01-1995.02

M1 $\quad$ Narrow monetary aggregates

FRANCE SA; monthly, 1977.12-1995.01

GERMANY SA; monthly, 1973.01-1995.02

ITALY SA; monthly average, 1985.01-1994.12

UK SA; monthly, 1982.06-1990.10

US SA; monthly, 1973.01-1995.02

$\underline{\text { M2/M3 } \quad \text { Broad money aggregates }}$

FRANCE M3, SA; monthly, 1977.12-1995.01

GERMANY M3, SA; monthly, 1973.01-1995.02

ITALY M3, SA; monthly, 1974.12-1984.12

M3 (harmonized), SA; monthly 1985.01-1994.12

UK M3, SA; monthly, 1973.01-1986.09

M3 (harmonized), SA; monthly 1986.10-1994.12

US M2; monthly, 1973.01-1995.02 
LEAD Leading economic indicators

UK Shorter leading cyclical indicator, SA; monthly, 1973.01-1995.02

US Composite index of leading indicators, $(1987=100)$; monthly, 1973.01-1995.02

\section{RECESSION}

A 1,0 series was created to identify the recessions, using NBER dates for US business cycles and Center for International Business Cycle Research dates for the business cycle in each European country. The series has a 1 from the period after the peak of the business cycle to the trough of the business cycle and a 0 from the period after the trough of the business cycle, to the period when the business cycle peaks. 


\section{Appendix; some additional results}

This appendix contains results that reinforce those presented in the text and demonstrate their robustness, but are not essential to the basic thrust of the paper.

Tables A1 and A2 are analogues to Table 2 in the text in that they test the ability of the yield curve SPREAD to predict real activity. In these cases, however, activity is measured by the growth in industrial production and by changes in unemployment, respectively, rather than by real GDP growth. The overall results are generally consistent across measures, with a few exceptions. For example, industrial production is not predicted very well in France nor is unemployment in the United Kingdom.

Table A3 is comparable to Table 3 of the text, with a recession dummy used as the dependent variable as a measure of real activity. Whereas Table 3 reports results with quarterly data, in Table A3 the periodicity is monthly. There are no significant qualitative or even quantitative differences between the two tables. 


\section{Notes}

1. Estrella and Hardouvelis (1990) looked at various issues covered in the present paper in the US context. Bernanke and Mishkin (1992) contains cross country analysis of some of the same issues, focusing on shorter-term horizons than in the present paper and using monthly data.

2. See, for example, Bernanke and Blinder (1992) and Bernanke and Mihov (1995). Useful discussions of the conduct of monetary policy in most of the countries studied in this paper may be found in Kneeshaw and Van den Bergh (1989) and Kasman (1992).

3. The analysis in all sections of the paper was performed with the SPREAD defined as both the difference between the BOND and BILL rates and also the difference between the BOND and central bank (CB) rates. Qualitatively, the results were very similar and neither variable dominated the other in the prediction of real activity and inflation. The results reported in the text correspond to BOND-BILL, which does outperform the alternative variable in the prediction of real GDP growth and recessions one to two years ahead (section 3), and with which the analysis of central bank credibility in this section is much clearer.

4. Katharine Campbell, "Bundesbank lifts Lombard rate to fight deficits", Financial Times, November 2, 1990.

5. In France, monetary policy operating procedures over most of the sample period created an unusually close relationship between the central bank rate and the bill rate. Since the bill rate appears in the spread with a negative sign, the regression coefficient tends to be close to -1 . For a brief discussion of the French procedures and further references, see Kneeshaw and Van den Bergh (1989).

6. There is some evidence of a break in the estimates for the United States in October 1979. The full-sample results are very similar qualitatively and quantitatively to the results after the break. For convenience and space considerations, only the full-sample estimates are presented in the table. The estimates in the earlier part of the sample tend to be stronger (larger coefficients and $\mathbf{R}^{2}$ s) for shorter horizons (up to seven quarters).

7. Various measures of fit have been proposed for an equation with a dichotomous dependent variable, e.g., probit, and with a constant term (see, e.g., Maddala (1983)). The measure used here is

$$
\phi=1-\left(\frac{\log L_{u}}{\log L_{c}}\right)^{-\frac{2}{\operatorname{NOBS}} \log L_{c}},
$$

where $\mathrm{L}_{\mathrm{u}}$ and $\mathrm{L}_{\mathrm{c}}$ are the unconstrained and constrained likelihood, respectively. Estrella (1995) shows that this measure has several desirable properties that earlier alternatives lack. 
8. Principal components analysis was applied to contemporaneous and 6 lags of monthly changes in the BILL and BOND rates for each of the five countries over the January 1973 to February 1995 period. In Germany, the first principal component accounted for more than 30 percent of the total variance. In the other countries, the corresponding figures ranged from 17 to 21 percent.

9. For example, Watson (1991) and Stock and Watson (1992) discuss the reasons for the failure of the Stock-Watson (1989) index of leading indicators -- which relies significantly on the yield curve slope -- in predicting the 1990-91 recession. They obtain different results from the ones we find here because their approach differs from ours in three major ways. First, Stock and Watson use altogether seven predictive variables, which tend produce a good in-sample fit, but may lead to overfitting for predictive purposes. Second, they use a vector autoregressive methodology that does not distinguish among different predictive horizons in the estimation stage. Finally, the longest predictive horizon they consider is six months, whereas our results indicate that the best predictive fits are two to three times longer.

10. See Mishkin (1990a) for a derivation of this relationship.

11. Other recent work on the relationship between the term structure and future inflation includes Davis and Henry (1994), Davis and Fagan (1994) and Barran et al. (1995).

12. As with the predictions of real activity, there is some evidence of a break in the US results in October 1979. Again, the full sample results are similar to those in the latter part of the sample, and only the former are reported.

13. This follows directly from Goodhart's Law and the Lucas (1976) Critique. 


\section{References}

Barran, Fernando, Virginie Coudert and Benoit Mojon, "Interest Rates, Banking Spreads and Credit Supply: The Real Effects", Centre D'Etudes Prospectives et D'Informations Internationales, Working Paper No. 95-01 (March).

Bernanke, Ben and Alan Blinder, 1992, "The Federal Funds Rate and the Channels of Monetary Transmission", American Economic Review, 82 (September).

Bernanke, Ben and Ilian Mihov, 1995, "Measuring Monetary Policy", Draft, March.

Bernanke, Ben and Frederic Mishkin, 1992, "The Predictive Power of Interest Rate Spreads: Evidence from Six Industrialized Economies", Draft, December.

Bomhoff, Eduard J., 1994, Financial Forecasting for Business and Economics, Academic Press.

Chen, Nai-Fu, 1991, "Financial Investment Opportunities and the Macroeconomy", Journal of Finance, 46:2 (June). 
Davis, E. Philip and S.G.B. Henry, 1994, "The Use of Financial Spreads as Indicator Variables: Evidence for the United Kingdom and Germany, IMF Staff Papers, 41:3 (September).

Davis, E. Philip and Gabriel Fagan, "Indicator Properties of Financial Spreadsin the EU: Evidence from Aggregate Union Data", European Monetary Institute working paper.

Estrella, Arturo, 1995, "Measures of Fit with Dichotomous Dependent Variables: Critical Review and a New Proposal", Federal Reserve Bank of New York Research Paper (August).

Estrella, Arturo and Gikas Hardouvelis, 1991, "The Term Structure as a Predictor of Real Economic Activity", Journal of Finance, 46:2 (June).

Estrella, Arturo and Gikas Hardouvelis, 1990, "Possible Roles of the Yield Curve in Monetary Analysis", in Intermediate Targets and Indicators for Monetary Policy, Federal Reserve Bank of New York.

Fisher, Irving, 1930, The Theory of Interest, Macmillan.

Harvey, Andrew, 1990, The Econometric Analysis of Time Series, MIT. 
Harvey, Campbell, 1988, "The Real Term Structure and Consumption Growth", Џournal of Financial Economics, 22.

Huizinga, John and Frederic S. Mishkin, 1986, "Monetary Policy Regime Shifts and the Unusual Behavior of Real Interest Rates, " Carnegie-Rochester Conference Series on Public Policy, 24 (Spring): 231-74.

Jorion, Phillippe and Frederic S. Mishkin, 1991, "A Multi-Country Comparison of Term Structure Forecasts at Long Horizons," Journal of Financial Economics, 29, (January): 5980.

Kasman, Bruce, 1992, "A Comparison of Monetary Policy Operating Procedures in Six Industrial Countries", Federal Reserve Bank of New York Quarterly Review, 17:2, Summer.

Kneeshaw, J.T. and P. Van den Bergh, 1989, "Changes in Central Bank Money Market Operating Procedures in the 1980s", BIS Economic Papers, no. 23, January, Basle.

Laurent, Robert, 1988, "An Interest Rate-Based Indicator of Monetary Policy", Federal Reserve Bank of Chicago Economic Perspectives, 12, January/February.

Laurent, Robert, 1989, "Testing the Spread", Federal Reserve Bank of Chicago Economic Perspectives, 13, July/August. 
Lucas, Robert, 1976, "Econometric Policy Evaluation: A Critique", in Brunner, Karl and Allan Meltzer, eds., The Phillips Curve and Labor Markets, Carnegie-Rochester Conference Series in Public Policy, 1, North Holland.

Maddala, G.S., 1983, Limited-Dependent and Qualitative Variables in Econometrics, Cambridge University Press.

McCallum, Bennett T., 1976, "Rational Expectations and the Natural Rate Hypothesis: Some Consistent Estimates," Econometrica 44: 43-52.

Mishkin, Frederic S., 1990a, "What Does the Term Structure Tell Us About Future Inflation?" Journal of Monetary Economics 25 (January): 77-95.

Mishkin, Frederic S., 1990b, "The Information in the Longer-Maturity Term Structure About Future Inflation," Quarterly Journal of Economics, 55, (August):815-28.

Mishkin, Frederic S., 1991, "A Multi-Country Study of the Information in the Term Structure About Future Inflation," Journal of International Money and Finance, 19, (March): $2-22$. 
Newey, Whitney and Kenneth West, 1987, "A Simple Positive Semi-Definite, Heteroskedasticity and Autocorrelation Consistent Covariance Matrix", Econometrica, 55, May.

Pagan, Adrian, 1984, "Econometric Issues in the Analysis of Regressions with Generated Regressors," International Economic Review, 25: 221-47.

Stock, James and Mark Watson, 1989, "New Indexes of Coincident and Leading Indicators", in Blanchard, Olivier and Stanley Fischer, eds. NBER Macroeconomic Annual, 4.

Stock, James and Mark Watson, 1992, "A Procedure for Predicting Recessions with Leading Indicators: Econometric Issues and Recent Performance", Federal Reserve Bank of Chicago Working Paper WP-92-7, April.

Watson, Mark, 1991, "Using Econometric Models to Predict Recessions", Federal Reserve Bank of Chicago Economic Perspectives, 15:6, November/December. 
Table 1

Contemporaneous Effect of Central Bank Rate

on Yield Curve Spread

Vector Autoregressions with Monthly Data

$$
S P R E A D_{t}=\alpha_{0}+\sum_{i=0}^{6} \beta_{i} C B_{t-i}+\sum_{i=1}^{6} \gamma_{i} B I L L_{t-i}+\sum_{i=1}^{6} \delta_{i} B O N D_{t-i}+\varepsilon_{t}
$$

\begin{tabular}{|c|c|c|c|c|c|c|}
\hline Country & $\beta_{0}$ & $\sum_{i=1}^{6} \beta_{i}$ & $\sum_{i=1}^{6} \gamma_{i}$ & $\sum_{i=1}^{6} \delta_{i}$ & $\overline{\mathbf{R}^{2}}$ & SEE \\
\hline $\begin{array}{l}\text { France } \\
6 / 78 \text { to } 2 / 95\end{array}$ & $\begin{array}{l}-.898^{*} \\
(.131)\end{array}$ & $\begin{array}{l}.725^{*} \\
(.187)\end{array}$ & $\begin{array}{l}-.779 * \\
(.132)\end{array}$ & $\begin{array}{l}.970^{*} \\
(.053)\end{array}$ & .820 & .642 \\
\hline $\begin{array}{l}\text { Germany } \\
7 / 73 \text { to } 2 / 95\end{array}$ & $\begin{array}{l}-.441^{*} \\
(.114)\end{array}$ & $\begin{array}{l}.258^{*} \\
(.113)\end{array}$ & $\begin{array}{l}-.800^{*} \\
(.035)\end{array}$ & $\begin{array}{l}.924^{*} \\
(.034)\end{array}$ & .953 & .423 \\
\hline $\begin{array}{l}\text { Italy } \\
10 / 81 \text { to } 2 / 95\end{array}$ & $\begin{array}{l}-.201 * \\
(.046)\end{array}$ & $\begin{array}{l}.158 * \\
(.057)\end{array}$ & $\begin{array}{l}-.825^{*} \\
(.063)\end{array}$ & $\begin{array}{l}.880^{*} \\
(.057)\end{array}$ & .753 & .523 \\
\hline $\begin{array}{l}\text { United Kingdom } \\
4 / 78 \text { to } 2 / 95\end{array}$ & $\begin{array}{l}-.232 * \\
(.034)\end{array}$ & $\begin{array}{l}.207^{*} \\
(.073)\end{array}$ & $\begin{array}{l}-.922^{*} \\
(.083)\end{array}$ & $\begin{array}{l}.939 * \\
(.025)\end{array}$ & .938 & .464 \\
\hline $\begin{array}{l}\text { United States } \\
7 / 73 \text { to } 2 / 95\end{array}$ & $\begin{array}{l}-.519^{*} \\
(.033)\end{array}$ & $\begin{array}{l}.356^{*} \\
(.055)\end{array}$ & $\begin{array}{l}-.735^{*} \\
(.066)\end{array}$ & $\begin{array}{l}.897^{*} \\
(.025)\end{array}$ & .955 & .331 \\
\hline $7 / 73$ to $10 / 79$ & $\begin{array}{l}-.290^{*} \\
(.090)\end{array}$ & $\begin{array}{l}.140 \\
(.101)\end{array}$ & $\begin{array}{l}-.720^{*} \\
(.156)\end{array}$ & $\begin{array}{l}.717^{*} \\
(.121)\end{array}$ & .958 & .302 \\
\hline $11 / 79$ to $2 / 95$ & $\begin{array}{l}-.580^{*} \\
(.041)\end{array}$ & $\begin{array}{l}.349^{*} \\
(.095)\end{array}$ & $\begin{array}{l}-.662^{*} \\
(.108)\end{array}$ & $\begin{array}{c}.900^{*} \\
(.030)\end{array}$ & .957 & .321 \\
\hline
\end{tabular}

Notes: SPREAD ${ }_{\mathrm{t}}$ is the difference between the ten-year government bond and three-month government bill rates. Standard errors (Newey-West (1987)) in parentheses. Asterisks denote significance at the 5\% level. 
Sample: Quarterly, 1973 to 1994

$(400 / \mathrm{k})\left(\log \mathrm{Y}_{\mathrm{t}+\mathrm{k}}-\log \mathrm{Y}_{\mathrm{J}}\right)=\alpha_{0}+\alpha_{1} \operatorname{SPREAD}_{\mathrm{t}}+\epsilon_{\mathrm{t}}$

\begin{tabular}{|c|c|c|c|c|c|c|c|c|c|c|}
\hline \multirow{2}{*}{$\begin{array}{l}\text { k (Quarters } \\
\text { Ahead) } \\
\end{array}$} & \multicolumn{2}{|c|}{ France } & \multicolumn{2}{|c|}{ Germany } & \multicolumn{2}{|c|}{ Italy } & \multicolumn{2}{|c|}{ United Kingdom } & \multicolumn{2}{|c|}{ United States } \\
\hline & $\alpha_{1}$ & $\mathbf{R}^{2}$ & $\boldsymbol{\alpha}_{1}$ & $\mathbf{R}^{2}$ & $\alpha_{1}$ & $\mathbf{R}^{2}$ & $\alpha_{1}$ & $\overline{\mathbf{R}^{2}}$ & $\alpha_{1}$ & $\mathbf{R}^{2}$ \\
\hline 1 & $\begin{array}{c}.38 \\
(.21)\end{array}$ & .04 & $\begin{array}{c}.61^{*} \\
(.18)\end{array}$ & .06 & $\begin{array}{l}.05 \\
(.50)\end{array}$ & -.01 & $\begin{array}{c}.32 \\
(.20)\end{array}$ & .01 & $\begin{array}{l}1.13^{*} \\
(.25)\end{array}$ & .21 \\
\hline 2 & $\begin{array}{c}.43^{*} \\
(.20)\end{array}$ & .11 & $\begin{array}{c}.63 * \\
(.14)\end{array}$ & .15 & $\begin{array}{c}.20 \\
(.46)\end{array}$ & -.00 & $\begin{array}{c}.34 \\
(.19)\end{array}$ & .04 & $\begin{array}{l}1.24^{*} \\
(.19)\end{array}$ & .38 \\
\hline 3 & $\begin{array}{c}.49 * \\
(.18)\end{array}$ & .18 & $\begin{array}{l}.64^{*} \\
(.13)\end{array}$ & .24 & $\begin{array}{c}.37 \\
(.39)\end{array}$ & .05 & $\begin{array}{c}.34 \\
(.18)\end{array}$ & .06 & $\begin{array}{l}1.20^{*} \\
(.16)\end{array}$ & .47 \\
\hline 4 & $\begin{array}{c}.49 * \\
(.16)\end{array}$ & .22 & $\begin{array}{c}.66^{*} \\
(.11)\end{array}$ & .32 & $\begin{array}{c}.48 \\
(.33)\end{array}$ & .12 & $\begin{array}{l}.35^{*} \\
(.17)\end{array}$ & .08 & $\begin{array}{l}1.16^{*} \\
(.15)\end{array}$ & .53 \\
\hline 5 & $\begin{array}{l}.51^{*} \\
(.15)\end{array}$ & .27 & $\begin{array}{c}.65 * \\
(.10)\end{array}$ & .34 & $\begin{array}{c}.48 \\
(.31)\end{array}$ & .13 & $\begin{array}{l}.38 * \\
(.16)\end{array}$ & .12 & $\begin{array}{l}1.10^{*} \\
(.14)\end{array}$ & .57 \\
\hline 6 & $\begin{array}{l}.45^{*} \\
(.15)\end{array}$ & .23 & $\begin{array}{l}.62^{*} \\
(.09)\end{array}$ & .38 & $\begin{array}{c}.41 \\
(.29)\end{array}$ & .10 & $\begin{array}{l}.35 * \\
(.16)\end{array}$ & .12 & $\begin{array}{l}1.02^{*} \\
(.13)\end{array}$ & .58 \\
\hline 7 & $\begin{array}{l}.48^{*} \\
(.15)\end{array}$ & .26 & $\begin{array}{c}.60^{*} \\
(.08)\end{array}$ & .40 & $\begin{array}{c}.30 \\
(.29)\end{array}$ & .05 & $\begin{array}{l}.33 * \\
(.16)\end{array}$ & .11 & $\begin{array}{c}.95^{*} \\
(.10)\end{array}$ & .56 \\
\hline 8 & $\begin{array}{l}.47^{*} \\
(.15)\end{array}$ & .24 & $\begin{array}{c}.56 * \\
(.07)\end{array}$ & .39 & $\begin{array}{c}.21 \\
(.27)\end{array}$ & .02 & $\begin{array}{c}.30 \\
(.17)\end{array}$ & .09 & $\begin{array}{c}.86^{*} \\
(.08)\end{array}$ & .52 \\
\hline 12 & $\begin{array}{l}.46 * \\
(.17)\end{array}$ & .24 & $\begin{array}{c}.39 * \\
(.08)\end{array}$ & .31 & $\begin{array}{l}-.06 \\
(.19)\end{array}$ & -.01 & $\begin{array}{l}.16 \\
(.18)\end{array}$ & .03 & $\begin{array}{l}.56 * \\
(.10)\end{array}$ & .35 \\
\hline 16 & $\begin{array}{c}.44^{*} \\
(.18)\end{array}$ & .29 & $\begin{array}{c}.28 * \\
(.07)\end{array}$ & .23 & $\begin{array}{l}-.13 \\
(.14)\end{array}$ & .01 & $\begin{array}{l}.10 \\
(.15)\end{array}$ & .01 & $\begin{array}{c}.26 * \\
(.09)\end{array}$ & .11 \\
\hline 20 & $\begin{array}{l}.30^{*} \\
(.13)\end{array}$ & .15 & $\begin{array}{l}.16^{*} \\
(.07)\end{array}$ & .11 & $\begin{array}{l}-.10 \\
(.12)\end{array}$ & .01 & $\begin{array}{l}.01 \\
(.13)\end{array}$ & -.01 & $\begin{array}{c}.07 \\
(.08)\end{array}$ & .00 \\
\hline
\end{tabular}

Notes: $Y_{t}$ is the level of real GDP of quarter $t$. SPREAD is the difference between the ten-year government bond and three-month government bill rates. The interest rates are annualized quarterly-average bond-equivalent yields. In parentheses are Newey-West (1987) corrected standard errors that take into account the moving average created by the overlapping of forecasting horizons as well as conditional heteroskedasticity.

*Significant at 5 percent level. 


\section{Table 3}

Predicting Recessions Using the Yield Curve Spread

Sample: Quarterly, 1973 to 1994

P $\left(\right.$ RECESSION $\left._{t}=1\right)=F\left(\alpha_{0}+\alpha_{1}\right.$ SPREAD $_{t-4}+\alpha_{2}$ LI $\left._{t-4}\right)$

\begin{tabular}{|c|c|c|c|c|}
\hline Country & Observations & $\alpha_{1}$ & $\alpha_{2}$ & $\phi$ \\
\hline France & 62 & $\begin{array}{l}-.054 \\
(.113)\end{array}$ & & .004 \\
\hline Germany & 83 & $\begin{array}{l}-.785 * \\
(.148)\end{array}$ & & .577 \\
\hline Italy & 69 & $\begin{array}{l}-.314^{*} \\
(.130)\end{array}$ & & .096 \\
\hline \multirow[t]{2}{*}{ United Kingdom } & 84 & $\begin{array}{l}-.311^{*} \\
(.080)\end{array}$ & & .206 \\
\hline & 83 & $\begin{array}{l}-.292^{*} \\
(.081)\end{array}$ & $\begin{array}{c}-11.5 \\
(6.66)\end{array}$ & .259 \\
\hline \multirow[t]{2}{*}{ United States } & 84 & $\begin{array}{l}-.699 * \\
(.154)\end{array}$ & & .361 \\
\hline & 83 & $\begin{array}{l}-.725^{*} \\
(.164)\end{array}$ & $\begin{array}{r}2.86 \\
(16.3)\end{array}$ & .423 \\
\hline
\end{tabular}

Equation is estimated using probit, that is, $\mathrm{F}$ is the cumulative normal distribution. Dependent variable is RECESSION $_{t}=0$ or 1 . SPREAD is the difference between the ten-year government bond and threemonth government bill rates. $\mathrm{LI}_{\mathrm{t}}$ is the growth in the index of leading indicators from the first month of quarter $t-1$ to the first month of quarter $t$. LI is only available for the UK and the US. The last column contains a measure of fit analogous to $\mathrm{R}^{2}$ in a linear regression. This measure is defined as

$$
\phi=1-\left(\frac{\log L_{u}}{\log L_{c}}\right)^{-\frac{2}{\operatorname{NOBS}} \log L_{c}},
$$

where $\mathrm{L}_{\mathrm{u}}$ and $\mathrm{L}_{\mathrm{c}}$ are the unconstrained and constrained $\left(\alpha_{1}=\alpha_{2}=0\right)$ likelihood, respectively. See Estrella (1995) for a discussion of $\phi$ and other measures of fit for probit equations.

*Significant at the $5 \%$ level. 
$(400 / k)\left(\log Y_{t+k}-\log Y_{j}\right)=\alpha_{0}+\alpha_{1} S_{P R E A D}+\alpha_{2} X_{t}+\epsilon_{t}$

\begin{tabular}{|c|c|c|c|c|c|c|c|c|c|c|c|}
\hline \multirow[b]{2}{*}{$\mathbf{X}$} & \multirow{2}{*}{$\begin{array}{l}\text { k (Quarters } \\
\text { Ahead) }\end{array}$} & \multicolumn{2}{|c|}{ France } & \multicolumn{2}{|c|}{ Germany } & \multicolumn{2}{|c|}{ Italy } & \multicolumn{2}{|c|}{ United Kingdom } & \multicolumn{2}{|c|}{ United States } \\
\hline & & $\alpha_{1}$ & $\alpha_{2}$ & $\alpha_{1}$ & $\alpha_{2}$ & $\alpha_{1}$ & $\alpha_{2}$ & $\alpha_{1}$ & $\alpha_{2}$ & $\alpha_{1}$ & $\alpha_{2}$ \\
\hline \multirow[t]{3}{*}{$\cdots$} & 4 & $\begin{array}{l}.49 * \\
(.16)\end{array}$ & & $\begin{array}{l}.66^{*} \\
(.11)\end{array}$ & & $\begin{array}{c}.48 \\
(.33)\end{array}$ & & $\begin{array}{l}.35 * \\
(.17)\end{array}$ & & $\begin{array}{l}1.16^{*} \\
(.15)\end{array}$ & . \\
\hline & 6 & $\begin{array}{l}.45 * \\
(.15)\end{array}$ & & $\begin{array}{l}.62 * \\
(.09)\end{array}$ & & $\begin{array}{c}.41 \\
(.29)\end{array}$ & & $\begin{array}{l}.35 * \\
(.16)\end{array}$ & & $\begin{array}{l}1.02^{*} \\
(.13)\end{array}$ & \\
\hline & 8 & $\begin{array}{l}.47 * \\
(.15)\end{array}$ & & $\begin{array}{l}.56 * \\
(.07)\end{array}$ & & $\begin{array}{c}.21 \\
(.27)\end{array}$ & & $\begin{array}{l}.30 \\
(.17)\end{array}$ & & $\begin{array}{l}.86^{*} \\
(.08)\end{array}$ & \\
\hline \multirow[t]{3}{*}{$\mathrm{CB}$} & 4 & $\begin{array}{l}.49 * \\
(.14)\end{array}$ & $\begin{array}{l}-.24 * \\
(.12)\end{array}$ & $\begin{array}{c}.35 \\
(.19)\end{array}$ & $\begin{array}{l}-.37 \\
(.22)\end{array}$ & $\begin{array}{c}.83 * \\
(.26)\end{array}$ & $\begin{array}{l}-.21 * \\
(.11)\end{array}$ & $\begin{array}{c}.21 \\
(.22)\end{array}$ & $\begin{array}{l}-.33^{*} \\
(.15)\end{array}$ & $\begin{array}{l}1.10 * \\
(.24)\end{array}$ & $\begin{array}{l}-.04 \\
(.11)\end{array}$ \\
\hline & 6 & $\begin{array}{l}.43 * \\
(.13)\end{array}$ & $\begin{array}{l}-.21 * \\
(.09)\end{array}$ & $\begin{array}{l}.42^{*} \\
(.15)\end{array}$ & $\begin{array}{l}-.24 \\
(.13)\end{array}$ & $\begin{array}{l}.71^{*} \\
(.16)\end{array}$ & $\begin{array}{l}-.14 \\
(.12)\end{array}$ & $\begin{array}{c}.23 \\
(.25)\end{array}$ & $\begin{array}{l}-.29 * \\
(.14)\end{array}$ & $\begin{array}{l}1.09 * \\
(.23)\end{array}$ & $\begin{array}{l}.04 \\
(.10)\end{array}$ \\
\hline & 8 & $\begin{array}{l}.43^{*} \\
(.16)\end{array}$ & $\begin{array}{l}-.17 * \\
(.09)\end{array}$ & $\begin{array}{l}.36 * \\
(.15)\end{array}$ & $\begin{array}{l}-.23 \\
(.15)\end{array}$ & $\begin{array}{l}.54^{*} \\
(.15)\end{array}$ & $\begin{array}{l}-.06 \\
(.13)\end{array}$ & $\begin{array}{c}.21 \\
(.31)\end{array}$ & $\begin{array}{l}-.20 \\
(.13)\end{array}$ & $\begin{array}{l}.97 * \\
(.20)\end{array}$ & $\begin{array}{l}.08 \\
(.11)\end{array}$ \\
\hline \multirow[t]{3}{*}{$\mathrm{RCB}$} & 4 & $\begin{array}{c}.46 \\
(.26)\end{array}$ & $\begin{array}{l}-.03 \\
(.14)\end{array}$ & $\begin{array}{l}.56 * \\
(.16)\end{array}$ & $\begin{array}{l}-.25 \\
(.31)\end{array}$ & $\begin{array}{l}.40 \\
(.56)\end{array}$ & $\begin{array}{l}-.08 \\
(.29)\end{array}$ & $\begin{array}{l}.87 * \\
(.16)\end{array}$ & $\begin{array}{l}.33 * \\
(.09)\end{array}$ & $\begin{array}{l}1.10^{*} \\
(.17)\end{array}$ & $\begin{array}{l}-.10 \\
(.10)\end{array}$ \\
\hline & 6 & $\begin{array}{l}.44 * \\
(.23)\end{array}$ & $\begin{array}{l}-.00 \\
(.11)\end{array}$ & $\begin{array}{l}.53 * \\
(.13)\end{array}$ & $\begin{array}{l}-.18 \\
(.16)\end{array}$ & $\begin{array}{c}.64 \\
(.50)\end{array}$ & $\begin{array}{c}.11 \\
(.22)\end{array}$ & $\begin{array}{l}.82 * \\
(.15)\end{array}$ & $\begin{array}{l}.32 * \\
(.08)\end{array}$ & $\begin{array}{c}.99 * \\
(.14)\end{array}$ & $\begin{array}{l}-.04 \\
(.10)\end{array}$ \\
\hline & 8 & $\begin{array}{c}.53 * \\
(.22)\end{array}$ & $\begin{array}{c}.05 \\
(.09)\end{array}$ & $\begin{array}{l}.42 * \\
(.14)\end{array}$ & $\begin{array}{l}-.26 \\
(.21)\end{array}$ & $\begin{array}{l}.93 * \\
(.37)\end{array}$ & $\begin{array}{l}.37 * \\
(.12)\end{array}$ & $\begin{array}{l}.74 * \\
(.21)\end{array}$ & $\begin{array}{l}.35 * \\
(.08)\end{array}$ & $\begin{array}{l}.83 * \\
(.10)\end{array}$ & $\begin{array}{l}-.01 \\
(.12)\end{array}$ \\
\hline \multirow[t]{3}{*}{ BILL } & 4 & $\begin{array}{l}.43^{*} \\
(.14)\end{array}$ & $\begin{array}{l}-.23 \\
(.12)\end{array}$ & $\begin{array}{c}.03 \\
(.32)\end{array}$ & $\begin{array}{l}-.50^{*} \\
(.23)\end{array}$ & $\begin{array}{c}.42 \\
(.33)\end{array}$ & $\begin{array}{l}-.28 * \\
(.08)\end{array}$ & $\begin{array}{c}.01 \\
(.20)\end{array}$ & $\begin{array}{l}-.46^{*} \\
(.17)\end{array}$ & $\begin{array}{l}1.14^{*} \\
(.22)\end{array}$ & $\begin{array}{l}-.02 \\
(.12)\end{array}$ \\
\hline & 6 & $\begin{array}{l}.38 * \\
(.13)\end{array}$ & $\begin{array}{l}-.20^{*} \\
(.10)\end{array}$ & $\begin{array}{c}.07 \\
(.28)\end{array}$ & $\begin{array}{l}-.43^{*} \\
(.18)\end{array}$ & $\begin{array}{c}.36 \\
(.29)\end{array}$ & $\begin{array}{l}-.23 * \\
(.10)\end{array}$ & $\begin{array}{l}.05 \\
(.21)\end{array}$ & $\begin{array}{l}-.42 * \\
(.17)\end{array}$ & $\begin{array}{l}1.08 * \\
(.21)\end{array}$ & $\begin{array}{l}.04 \\
(.11)\end{array}$ \\
\hline & 8 & $\begin{array}{l}.40^{*} \\
(.16)\end{array}$ & $\begin{array}{l}-.17 \\
(.09)\end{array}$ & $\begin{array}{l}.15 \\
(.29)\end{array}$ & $\begin{array}{l}-.31 \\
(.20)\end{array}$ & $\begin{array}{l}.17 \\
(.28)\end{array}$ & $\begin{array}{l}-.14 \\
(.10)\end{array}$ & $\begin{array}{l}.11 \\
(.22)\end{array}$ & $\begin{array}{l}-.29 \\
(.19)\end{array}$ & $\begin{array}{l}.95^{*} \\
(.18)\end{array}$ & $\begin{array}{l}.08 \\
(.11)\end{array}$ \\
\hline
\end{tabular}

Notes: The first three lines reproduce results from Table 2 for comparison. Other regressions add as an explanatory variable the central bank rate (CB), the real $\mathrm{CB}$ rate (RCB), or the short-term government rate (BILL). The ex post RCB rate is instrumented with CB, SPREAD, and 2 lags of quarterly inflation.

*Significant at 5 percent level. 
$(400 / k)\left(\log Y_{t+k}-\log Y\right)=\alpha_{0}+\alpha_{1}$ SPREAD $+\alpha_{2} X_{1}+\epsilon_{1}$

\begin{tabular}{|c|c|c|c|c|c|c|c|c|c|c|c|}
\hline \multirow[b]{2}{*}{$\mathbf{X}$} & \multirow{2}{*}{$\begin{array}{l}\text { k (Quarters } \\
\text { Ahead) }\end{array}$} & \multicolumn{2}{|c|}{ France } & \multicolumn{2}{|c|}{ Germany } & \multicolumn{2}{|c|}{ Italy } & \multicolumn{2}{|c|}{ United Kingdom } & \multicolumn{2}{|c|}{ United States } \\
\hline & & $\alpha_{1}$ & $\alpha_{2}$ & $\alpha_{1}$ & $\alpha_{2}$ & $\alpha_{1}$ & $\alpha_{2}$ & $\boldsymbol{\alpha}_{1}$ & $\alpha_{2}$ & $\alpha_{1}$ & $\alpha_{2}$ \\
\hline \multirow[t]{3}{*}{--} & 4 & $\begin{array}{l}.49 * \\
(.16)\end{array}$ & & $\begin{array}{l}.66^{*} \\
(.11)\end{array}$ & & $\begin{array}{c}.48 \\
(.33)\end{array}$ & & $\begin{array}{l}.35 * \\
(.17)\end{array}$ & & $\begin{array}{l}1.16^{*} \\
(.15)\end{array}$ & \\
\hline & 6 & $\begin{array}{l}.45^{*} \\
(.15)\end{array}$ & & $\begin{array}{l}.62^{*} \\
(.09)\end{array}$ & & $\begin{array}{c}.41 \\
(.29)\end{array}$ & & $\begin{array}{l}.35^{*} \\
(.16)\end{array}$ & & $\begin{array}{l}1.02 * \\
(.13)\end{array}$ & \\
\hline & 8 & $\begin{array}{l}.47 * \\
(.15)\end{array}$ & & $\begin{array}{l}.56^{*} \\
(.07)\end{array}$ & & $\begin{array}{c}.21 \\
(.27)\end{array}$ & & $\begin{array}{c}.30 \\
(.17)\end{array}$ & & $\begin{array}{l}.86 * \\
(.08)\end{array}$ & \\
\hline \multirow[t]{3}{*}{ Mo } & 4 & $\begin{array}{r}.48^{*} \\
(0.16)\end{array}$ & $\begin{array}{c}1.47 \\
(1.71)\end{array}$ & $\begin{array}{r}.69 * \\
(0.11)\end{array}$ & $\begin{array}{l}-25.55 \\
(35.19)\end{array}$ & $\begin{array}{c}.48 \\
(0.32)\end{array}$ & $\begin{array}{c}2.16 \\
(2.08)\end{array}$ & $\begin{array}{c}.58^{*} \\
(0.16)\end{array}$ & $\begin{array}{l}-82.65^{*} \\
(28.49)\end{array}$ & $\begin{array}{l}1.14 * \\
(0.15)\end{array}$ & $\begin{array}{r}9.68 \\
(50.53)\end{array}$ \\
\hline & 6 & $\begin{array}{r}.44^{*} \\
(0.14)\end{array}$ & $\begin{array}{c}.68 \\
(1.43)\end{array}$ & $\begin{array}{r}.64^{*} \\
(0.09)\end{array}$ & $\begin{array}{l}-17.93 \\
(23.99)\end{array}$ & $\begin{array}{c}.41 \\
(0.28)\end{array}$ & $\begin{array}{c}1.28 \\
(1.49)\end{array}$ & $\begin{array}{c}.59 * \\
(0.13)\end{array}$ & $\begin{array}{l}-83.94 * \\
(22.45)\end{array}$ & $\begin{array}{c}1.00^{*} \\
(0.12)\end{array}$ & $\begin{array}{c}17.27 \\
(29.95)\end{array}$ \\
\hline & 8 & $\begin{array}{r}.47 * \\
(0.15)\end{array}$ & $\begin{array}{c}.04 \\
(1.00)\end{array}$ & $\begin{array}{r}.56 * \\
(0.07)\end{array}$ & $\begin{array}{l}-14.13 \\
(17.89)\end{array}$ & $\begin{array}{c}.21 \\
(0.27)\end{array}$ & $\begin{array}{c}.57 \\
(1.42)\end{array}$ & $\begin{array}{l}.55^{*} \\
(0.12)\end{array}$ & $\begin{array}{l}-86.66^{*} \\
(22.72)\end{array}$ & $\begin{array}{c}.84 * \\
(0.09)\end{array}$ & $\begin{array}{c}13.54 \\
(27.64)\end{array}$ \\
\hline \multirow[t]{3}{*}{ M1 } & 4 & $\begin{array}{l}.50^{*} \\
(.17)\end{array}$ & $\begin{array}{l}-1.76 \\
(9.95)\end{array}$ & $\begin{array}{l}.66 * \\
(.11)\end{array}$ & $\begin{array}{c}2.36 \\
(5.64)\end{array}$ & $\begin{array}{l}1.34 * \\
(.26)\end{array}$ & $\begin{array}{l}-20.01 \\
(13.48)\end{array}$ & $\begin{array}{l}.56^{*} \\
(.28)\end{array}$ & $\begin{array}{c}23.53 * \\
(10.79)\end{array}$ & $\begin{array}{l}1.14^{*} \\
(.14)\end{array}$ & $\begin{array}{c}3.38 \\
(17.80)\end{array}$ \\
\hline & 6 & $\begin{array}{l}.45^{*} \\
(.16)\end{array}$ & $\begin{array}{c}-.52 \\
(11.38)\end{array}$ & $\begin{array}{l}.61 * \\
(.09)\end{array}$ & $\begin{array}{c}1.80 \\
(4.82)\end{array}$ & $\begin{array}{l}1.09 * \\
(.20)\end{array}$ & $\begin{array}{r}-14.30 \\
(9.09)\end{array}$ & $\begin{array}{l}.59 * \\
(.26)\end{array}$ & $\begin{array}{l}22.74 * \\
(7.36)\end{array}$ & $\begin{array}{l}1.00^{*} \\
(.12)\end{array}$ & $\begin{array}{c}5.65 \\
(16.63)\end{array}$ \\
\hline & 8 & $\begin{array}{l}.47^{*} \\
(.15)\end{array}$ & $\begin{array}{c}: 86 \\
(11.61)\end{array}$ & $\begin{array}{l}.56 * \\
(.07)\end{array}$ & $\begin{array}{l}-1.72 \\
(6.80)\end{array}$ & $\begin{array}{l}.90^{*} \\
(.25)\end{array}$ & $\begin{array}{c}-14.04 * \\
(6.59)\end{array}$ & $\begin{array}{l}.67 * \\
(.25)\end{array}$ & $\begin{array}{l}18.56^{*} \\
(6.86)\end{array}$ & $\begin{array}{l}.83 * \\
(.10)\end{array}$ & $\begin{array}{c}8.28 \\
(19.01)\end{array}$ \\
\hline \multirow[t]{3}{*}{$\mathrm{M} 2 / \mathrm{M} 3$} & 4 & $\begin{array}{l}.51^{*} \\
(.15)\end{array}$ & $\begin{array}{c}-6.42 \\
(15.35)\end{array}$ & $\begin{array}{l}.66^{*} \\
(.11)\end{array}$ & $\begin{array}{c}3.62 \\
(10.42)\end{array}$ & $\begin{array}{l}.45 \\
(.28)\end{array}$ & $\begin{array}{c}22.68 \\
(19.80)\end{array}$ & $\begin{array}{l}.37 * \\
(.17)\end{array}$ & $\begin{array}{c}-1.32 \\
(13.38)\end{array}$ & $\begin{array}{l}1.16^{*} \\
(.12)\end{array}$ & $\begin{array}{l}63.93 * \\
(18.50)\end{array}$ \\
\hline & 6 & $\begin{array}{l}.42^{*} \\
(.14)\end{array}$ & $\begin{array}{c}10.00 \\
(15.30)\end{array}$ & $\begin{array}{l}.62^{*} \\
(.09)\end{array}$ & $\begin{array}{l}-5.67 \\
(8.11)\end{array}$ & $\begin{array}{c}.37 \\
(.21)\end{array}$ & $\begin{array}{c}34.87 \\
(22.40)\end{array}$ & $\begin{array}{l}.37^{*} \\
(.15)\end{array}$ & $\begin{array}{c}.10 \\
(12.31)\end{array}$ & $\begin{array}{l}1.01 * \\
(.10)\end{array}$ & $\begin{array}{l}53.73 * \\
(13.95)\end{array}$ \\
\hline & 8 & $\begin{array}{r}.44^{*} \\
(.14) \\
\end{array}$ & $\begin{array}{c}11.29 \\
(16.32) \\
\end{array}$ & $\begin{array}{l}.56 * \\
(.07) \\
\end{array}$ & $\begin{array}{c}-17.02 * \\
(7.28) \\
\end{array}$ & $\begin{array}{l}.16 \\
(.19)\end{array}$ & $\begin{array}{c}36.50 \\
(23.31)\end{array}$ & $\begin{array}{l}.32^{*} \\
(.16)\end{array}$ & $\begin{array}{c}-.08 \\
(11.11)\end{array}$ & $\begin{array}{l}.83^{*} \\
(.06)\end{array}$ & $\begin{array}{c}50.98 * \\
(12.18)\end{array}$ \\
\hline
\end{tabular}

Notes: The first three lines reproduce results from Table 2 for comparison. Other regressions add as an explanatory variable the one-quarter log change in a base (M0), narrow (M1) or broad (M2) monetary aggregate.

*Significant at 5 percent level. 
$\Pi_{\mathrm{t}, t+\mathbf{k}}=\alpha_{0}+\alpha_{1} \operatorname{SPREAD}_{\mathrm{t}}+\alpha_{2} \Pi_{\mathrm{t}-\mathrm{k}, \mathrm{t}}+\epsilon_{\mathrm{t}}$

\begin{tabular}{|c|c|c|c|c|c|c|c|c|c|c|}
\hline \multirow{2}{*}{$\begin{array}{l}\text { k (Quarters } \\
\text { Ahead) } \\
\end{array}$} & \multicolumn{2}{|c|}{ France } & \multicolumn{2}{|c|}{ Germany } & \multicolumn{2}{|c|}{ Italy } & \multicolumn{2}{|c|}{ United Kingdom } & \multicolumn{2}{|c|}{ United States } \\
\hline & $\boldsymbol{\alpha}_{1}$ & $\mathbf{R}^{2}$ & $\alpha_{1}$ & $\overline{\mathbf{R}}^{2}$ & $\alpha_{1}$ & $\overline{\mathbf{R}}^{2}$ & $\alpha_{1}$ & $\overline{\mathbf{R}^{2}}$ & $\alpha_{1}$ & $\overline{\mathbf{R}}^{2}$ \\
\hline 4 & $\begin{array}{c}.042 \\
(.134)\end{array}$ & .04 & $\begin{array}{c}.083 \\
(.076)\end{array}$ & -.02 & $\begin{array}{c}.513 \\
(.302)\end{array}$ & .11 & $\begin{array}{l}-.048 \\
(.239)\end{array}$ & .02 & $\begin{array}{l}.108 \\
(.148)\end{array}$ & -.01 \\
\hline 8 & $\begin{array}{l}-.059 \\
(.148)\end{array}$ & -.03 & $\begin{array}{l}.177^{*} \\
(.065)\end{array}$ & -.00 & $\begin{array}{c}.852 \\
(.501)\end{array}$ & .11 & $\begin{array}{l}.229 \\
(.322)\end{array}$ & .08 & $\begin{array}{c}.261 \\
(.210)\end{array}$ & .06 \\
\hline 9 & $\begin{array}{l}-.097 \\
(.196)\end{array}$ & -.03 & $\begin{array}{l}.194 * \\
(.083)\end{array}$ & .01 & $\begin{array}{l}1.032^{*} \\
(.466)\end{array}$ & .18 & $\begin{array}{c}.497 \\
(.323)\end{array}$ & .06 & $\begin{array}{c}.319 \\
(.220)\end{array}$ & .08 \\
\hline 10 & $\begin{array}{l}-.042 \\
(.142)\end{array}$ & -.04 & $\begin{array}{l}.205 * \\
(.094)\end{array}$ & .01 & $\begin{array}{l}1.143^{*} \\
(.457)\end{array}$ & .20 & $\begin{array}{c}.502 \\
(.312)\end{array}$ & .09 & $\begin{array}{c}.367 \\
(.206)\end{array}$ & .11 \\
\hline 11 & $\begin{array}{l}-.050 \\
(.193)\end{array}$ & -.02 & $\begin{array}{c}.237 * \\
(.057)\end{array}$ & .06 & $\begin{array}{l}1.173 * \\
(.506)\end{array}$ & .20 & $\begin{array}{c}.577 \\
(.311)\end{array}$ & .11 & $\begin{array}{c}.537 * \\
(.181)\end{array}$ & .14 \\
\hline 12 & $\begin{array}{c}.052 \\
(.233)\end{array}$ & -.01 & $\begin{array}{c}.261 * \\
(.080)\end{array}$ & .01 & $\begin{array}{l}1.162^{*} \\
(.478)\end{array}$ & .18 & $\begin{array}{l}.656^{*} \\
(.311)\end{array}$ & .10 & $\begin{array}{l}.445 * \\
(.173)\end{array}$ & .19 \\
\hline 13 & $\begin{array}{c}.098 \\
(.220)\end{array}$ & -.04 & $\begin{array}{l}.287 * \\
(.072)\end{array}$ & .02 & $\begin{array}{c}.988 \\
(.610)\end{array}$ & .10 & $\begin{array}{l}.627^{*} \\
(.313)\end{array}$ & .11 & $\begin{array}{l}.569 * \\
(.154)\end{array}$ & .19 \\
\hline 14 & $\begin{array}{c}.078 \\
(.231)\end{array}$ & -.00 & $\begin{array}{l}.466 * \\
(.080)\end{array}$ & .10 & $\begin{array}{l}.887 \\
(.738)\end{array}$ & .04 & $\begin{array}{c}.588 \\
(.328)\end{array}$ & .10 & $\begin{array}{l}.589 * \\
(.150)\end{array}$ & .22 \\
\hline 15 & $\begin{array}{c}.049 \\
(.237)\end{array}$ & .00 & $\begin{array}{c}.319 * \\
(.092)\end{array}$ & .04 & $\begin{array}{l}1.017 \\
(.820)\end{array}$ & .12 & $\begin{array}{c}.578 \\
(.368)\end{array}$ & .09 & $\begin{array}{l}.541^{*} \\
(.123)\end{array}$ & .25 \\
\hline 16 & $\begin{array}{c}.033 \\
(.221)\end{array}$ & -.01 & $\begin{array}{l}.348 * \\
(.077)\end{array}$ & .04 & $\begin{array}{c}.972 \\
(1.022)\end{array}$ & .11 & $\begin{array}{c}.652 \\
(.379)\end{array}$ & .09 & $\begin{array}{l}.543 * \\
(.081)\end{array}$ & .29 \\
\hline 20 & $\begin{array}{c}.531 \\
(.359)\end{array}$ & .24 & $\begin{array}{l}.381 * \\
(.068)\end{array}$ & .14 & $\begin{array}{c}.756 \\
(1.072)\end{array}$ & .03 & $\begin{array}{l}.729 \\
(.499)\end{array}$ & .04 & $\begin{array}{l}.617^{*} \\
(.063)\end{array}$ & .51 \\
\hline
\end{tabular}

Notes: The dependent variable is defined as the annualized rate of inflation of the GDP price deflator from current quarter $t$ to future quarter $t+k$ minus the annualized rate of inflation from quarter $t-1$ to current quarter $t$. SPREAD, is the difference between the ten-year government bond and three-month government bill rates. All interest rates are annualized quarterly averages.

*Significant at 5 percent level. 
$(1200 / k)\left(\log \mathrm{IP}_{\mathrm{t}+\mathrm{k}}-\log \mathrm{IP}\right)=\alpha_{0}+\alpha_{1}$ SPREAD $_{\mathrm{t}}+\epsilon_{\mathrm{t}}$

\begin{tabular}{|c|c|c|c|c|c|c|c|c|c|c|}
\hline \multirow{2}{*}{$\begin{array}{l}\text { k (Months } \\
\text { Ahead) }\end{array}$} & \multicolumn{2}{|c|}{ France } & \multicolumn{2}{|c|}{ Germany } & \multicolumn{2}{|c|}{ Italy } & \multicolumn{2}{|c|}{ United Kingdom } & \multicolumn{2}{|c|}{ United States } \\
\hline & $\alpha_{1}$ & $\overline{R^{2}}$ & $\alpha_{1}$ & $\bar{R}^{2}$ & $\alpha_{1}$ & $\overrightarrow{\mathbf{R}^{2}}$ & $\alpha_{1}$ & $\bar{R}^{2}$ & $\alpha_{1}$ & $\mathbf{R}^{2}$ \\
\hline 3 & $\begin{array}{c}.65 * \\
(.32)\end{array}$ & .02 & $\begin{array}{l}1.16^{*} \\
(.37)\end{array}$ & .06 & $\begin{array}{c}.36 \\
(.83)\end{array}$ & -.00 & $\begin{array}{c}.58 \\
(.39)\end{array}$ & .01 & $\begin{array}{l}1.90^{*} \\
(.49)\end{array}$ & .15 \\
\hline 6 & $\begin{array}{c}.43 \\
(.26)\end{array}$ & .02 & $\begin{array}{l}1.22 * \\
(.32)\end{array}$ & .14 & $\begin{array}{c}.75 \\
(.82)\end{array}$ & .02 & $\begin{array}{c}.63 \\
(.40)\end{array}$ & .04 & $\begin{array}{l}1.94 * \\
(.45)\end{array}$ & .23 \\
\hline 9 & $\begin{array}{c}.40 \\
(.28)\end{array}$ & .04 & $\begin{array}{l}1.25^{*} \\
(.29)\end{array}$ & .22 & $\begin{array}{c}.87 \\
(.61)\end{array}$ & .05 & $\begin{array}{c}.59 \\
(.38)\end{array}$ & .05 & $\begin{array}{l}1.90^{*} \\
(.43)\end{array}$ & .30 \\
\hline 12 & $\begin{array}{c}.46 \\
(.27)\end{array}$ & .07 & $\begin{array}{l}1.29 * \\
(.25)\end{array}$ & .32 & $\begin{array}{l}1.04 * \\
(.46)\end{array}$ & .10 & $\begin{array}{l}.68 * \\
(.33)\end{array}$ & .10 & $\begin{array}{l}1.89 * \\
(.41)\end{array}$ & .38 \\
\hline 15 & $\begin{array}{c}.43 \\
(.26)\end{array}$ & .08 & $\begin{array}{l}1.29 * \\
(.21)\end{array}$ & .38 & $\begin{array}{l}1.03^{*} \\
(.41)\end{array}$ & .12 & $\begin{array}{l}.69 * \\
(.27)\end{array}$ & .14 & $\begin{array}{l}1.82^{*} \\
(.40)\end{array}$ & .42 \\
\hline 18 & $\begin{array}{c}.35 \\
(.25)\end{array}$ & .06 & $\begin{array}{l}1.27 * \\
(.19)\end{array}$ & .46 & $\begin{array}{l}.81^{*} \\
(.41)\end{array}$ & .09 & $\begin{array}{l}.63^{*} \\
(.22)\end{array}$ & .14 & $\begin{array}{l}1.74^{*} \\
(.39)\end{array}$ & .47 \\
\hline 21 & $\begin{array}{c}.28 \\
(.24)\end{array}$ & .05 & $\begin{array}{l}1.20^{*} \\
(.17)\end{array}$ & .48 & $\begin{array}{c}.54 \\
(.37)\end{array}$ & .05 & $\begin{array}{l}.58 * \\
(.18)\end{array}$ & .14 & $\begin{array}{l}1.62^{*} \\
(.32)\end{array}$ & .47 \\
\hline 24 & $\begin{array}{c}.38 \\
(.22)\end{array}$ & .09 & $\begin{array}{l}1.09 * \\
(.15)\end{array}$ & .47 & $\begin{array}{c}.39 \\
(.35)\end{array}$ & .03 & $\begin{array}{l}.50^{*} \\
(.18)\end{array}$ & .12 & $\begin{array}{l}1.42^{*} \\
(.26)\end{array}$ & .43 \\
\hline 36 & $\begin{array}{l}.59 * \\
(.21)\end{array}$ & .20 & $\begin{array}{l}.68 * \\
(.14)\end{array}$ & .35 & $\begin{array}{l}.10 \\
(.21)\end{array}$ & -.00 & $\begin{array}{c}.20 \\
(.20)\end{array}$ & .03 & $\begin{array}{l}.81^{*} \\
(.20)\end{array}$ & .30 \\
\hline 48 & $\begin{array}{c}.60 * \\
(.22)\end{array}$ & .29 & $\begin{array}{l}.44^{*} \\
(.12)\end{array}$ & .24 & $\begin{array}{l}-.02 \\
(.19)\end{array}$ & -.01 & $\begin{array}{l}.15 \\
(.15)\end{array}$ & .03 & $\begin{array}{c}.39 * \\
(.14)\end{array}$ & .12 \\
\hline 60 & $\begin{array}{l}.40^{*} \\
(.09)\end{array}$ & .18 & $\begin{array}{l}.20^{*} \\
(.07)\end{array}$ & .09 & $\begin{array}{l}-.12 \\
(.16)\end{array}$ & .01 & $\begin{array}{c}.05 \\
(.11)\end{array}$ & -.00 & $\begin{array}{l}.15 \\
(.10)\end{array}$ & .04 \\
\hline
\end{tabular}

Notes: IP, is the level of industrial production in month $\mathrm{t}$. SPREAD, is the difference between the ten-year government bond and three-month government bill rates. The interest rates are annualized quarterly-average bond-equivalent yields. In parentheses are Newey-West (1987) corrected standard errors that take into account the moving average created by the overlapping of forecasting horizons as well as conditional heteroskedasticity.

*Significant at 5 percent level. 
Predicting Future Change in Unemployment Using Yield Curve Spread

Sample: Monthly, 1973 to 1994 (Quarterly for Italy)

$U_{t+k}-U_{t}=\alpha_{0}+\alpha_{1}$ SPREAD $_{t}+\epsilon$

\begin{tabular}{|c|c|c|c|c|c|c|c|c|c|c|}
\hline \multirow{2}{*}{$\begin{array}{l}\text { k (Months } \\
\text { Ahead) }\end{array}$} & \multicolumn{2}{|c|}{ France } & \multicolumn{2}{|c|}{ Germany } & \multicolumn{2}{|c|}{ Italy } & \multicolumn{2}{|c|}{ United Kingdom } & \multicolumn{2}{|c|}{ United States } \\
\hline & $\alpha_{1}$ & $\overline{\mathbf{R}^{2}}$ & $\alpha_{1}$ & $\overline{\mathbf{R}^{2}}$ & $\alpha_{1}$ & $\overline{\mathbf{R}}^{2}$ & $\alpha_{1}$ & $\overline{\mathbf{R}^{2}}$ & $\alpha_{1}$ & $\overline{\mathrm{R}}^{2}$ \\
\hline 3 & $\begin{array}{l}-.07 * \\
(.01)\end{array}$ & .31 & $\begin{array}{l}-.06 * \\
(.01)\end{array}$ & .20 & $\begin{array}{c}.03 \\
(.04)\end{array}$ & -.01 & $\begin{array}{l}-.01 \\
(.02)\end{array}$ & -.00 & $\begin{array}{l}-.10 * \\
(.03)\end{array}$ & .14 \\
\hline 6 & $\begin{array}{l}-.13^{*} \\
(.03)\end{array}$ & .32 & $\begin{array}{l}. .13 * \\
(.02)\end{array}$ & .29 & $\begin{array}{c}.01 \\
(.09)\end{array}$ & -.02 & $\begin{array}{l}-.02 \\
(.05)\end{array}$ & .00 & $\begin{array}{l}-.23 * \\
(.05)\end{array}$ & .24 \\
\hline 9 & $\begin{array}{l}-.20 * \\
(.05)\end{array}$ & .34 & $\begin{array}{l}-.21^{*} \\
(.04)\end{array}$ & .35 & $\begin{array}{l}-.04 \\
(.15)\end{array}$ & -.02 & $\begin{array}{l}-.05 \\
(.08)\end{array}$ & .01 & $\begin{array}{l}-.36 * \\
(.07)\end{array}$ & .33 \\
\hline 12 & $\begin{array}{l}-.26 * \\
(.06)\end{array}$ & .33 & $\begin{array}{l}-.29 * \\
(.05)\end{array}$ & .41 & $\begin{array}{l}-.07 \\
(.20)\end{array}$ & -.01 & $\begin{array}{l}-.08 \\
(.11)\end{array}$ & .01 & $\begin{array}{l}-.50^{*} \\
(.09)\end{array}$ & .42 \\
\hline 15 & $\begin{array}{l}-.32^{*} \\
(.08)\end{array}$ & .35 & $\begin{array}{l}-.37 * \\
(.06)\end{array}$ & .47 & $\begin{array}{l}-.07 \\
(.26)\end{array}$ & -.02 & $\begin{array}{l}-.12 \\
(.14)\end{array}$ & .02 & $\begin{array}{l}-.63^{*} \\
(.10)\end{array}$ & .51 \\
\hline 18 & $\begin{array}{l}-.38^{*} \\
(.09)\end{array}$ & .36 & $\begin{array}{l}-.45 * \\
(.07)\end{array}$ & .52 & $\begin{array}{l}-.09 \\
(.32)\end{array}$ & -.01 & $\begin{array}{l}-.16 \\
(.16)\end{array}$ & .03 & $\begin{array}{l}-.74 * \\
(.11)\end{array}$ & .57 \\
\hline 21 & $\begin{array}{l}-.44 * \\
(.10)\end{array}$ & .37 & $\begin{array}{l}-.52 * \\
(.09)\end{array}$ & .55 & $\begin{array}{l}-.09 \\
(.36)\end{array}$ & -.02 & $\begin{array}{l}-.18 \\
(.17)\end{array}$ & .03 & $\begin{array}{l}-.83 * \\
(.11)\end{array}$ & .60 \\
\hline 24 & $\begin{array}{l}-.53^{*} \\
(.12)\end{array}$ & .38 & $\begin{array}{l}-.57 * \\
(.10)\end{array}$ & .55 & $\begin{array}{l}-.07 \\
(.40)\end{array}$ & -.02 & $\begin{array}{l}-.19 \\
(.18)\end{array}$ & .03 & $\begin{array}{l}-.88 * \\
(.10)\end{array}$ & .60 \\
\hline 36 & $\begin{array}{c}-1.20^{*} \\
(.16)\end{array}$ & .54 & $\begin{array}{l}-.65^{*} \\
(.13)\end{array}$ & .45 & $\begin{array}{l}-.59 \\
(.52)\end{array}$ & .05 & $\begin{array}{l}-.14 \\
(.25)\end{array}$ & .01 & $\begin{array}{l}-.91 * \\
(.15)\end{array}$ & .48 \\
\hline 48 & $\begin{array}{c}-1.47^{*} \\
(.14)\end{array}$ & .62 & $\begin{array}{l}-.64^{*} \\
(.14)\end{array}$ & .35 & $\begin{array}{l}1.37 * \\
(.31)\end{array}$ & .24 & $\begin{array}{l}-.01 \\
(.28)\end{array}$ & -.00 & $\begin{array}{l}-.69 * \\
(.15)\end{array}$ & .25 \\
\hline 60 & $\begin{array}{c}-1.26^{*} \\
(.11)\end{array}$ & .59 & $\begin{array}{l}-.50^{*} \\
(.18)\end{array}$ & .19 & $\begin{array}{l}1.26 * \\
(.29)\end{array}$ & .18 & $\begin{array}{c}.20 \\
(.27)\end{array}$ & .01 & $\begin{array}{l}-.41^{*} \\
(.18)\end{array}$ & .09 \\
\hline
\end{tabular}

Notes: $U_{t}$ is the unemployment rate for month $t$. SPREAD is the difference between the ten-year government bond and three-month government bill rates. The interest rates are annualized quarterly-average bond-equivalent yields. In parentheses are Newey-West (1987) corrected standard errors that take into account the moving average created by the overlapping of forecasting horizons as well as conditional heteroskedasticity.

*Significant at 5 percent level. 
Table A3

Predicting Recessions Using the Yield Curve Spread

Sample: Monthly, 1973 to 1994

P $\left(\right.$ RECESSION $\left._{t}=1\right)=\mathrm{F}\left(\alpha_{0}+\alpha_{1}\right.$ SPREAD $\left._{t-12}\right)$

\begin{tabular}{lccc}
\hline Country & Observations & $\alpha_{1}$ & $\phi$ \\
\hline France & 194 & .019 & .001 \\
& & $(.060)$ & \\
Germany & 253 & $-.774^{*}$ & .566 \\
& & $(.085)$ & \\
Italy & 218 & $-.235^{*}$ & .072 \\
& & $(.062)$ & .195 \\
United Kingdom & 254 & $-.298^{*}$ & \\
& & $(.045)$ & .351 \\
United States & 254 & & \\
& & $(.080)$ & \\
\hline
\end{tabular}

Equation is estimated using probit, that is, $\mathrm{F}$ is the cumulative normal distribution. Dependent variable is RECESSION $_{t}=0$ or 1 . SPREAD is the difference between the ten-year government bond and threemonth government bill rates. The last column contains a measure of fit analogous to $R^{2}$ in a linear regression. This measure is defined as

$$
\phi=1-\left(\frac{\log L_{u}}{\log L_{c}}\right)^{-\frac{2}{\operatorname{NOBS}} \log L_{c}},
$$

where $L_{u}$ and $L_{c}$ are the unconstrained and constrained $\left(\alpha_{1}=0\right)$ likelihood, respectively. See Estrella (1995) for a discussion of $\phi$ and other measures of fit for probit equations.

*Significant at the $5 \%$ level. 
CHART 1

a. Germany: 10-Year minus 3-Month Government Spread and the Lombard Rate Spread In basis points

Lombard rate

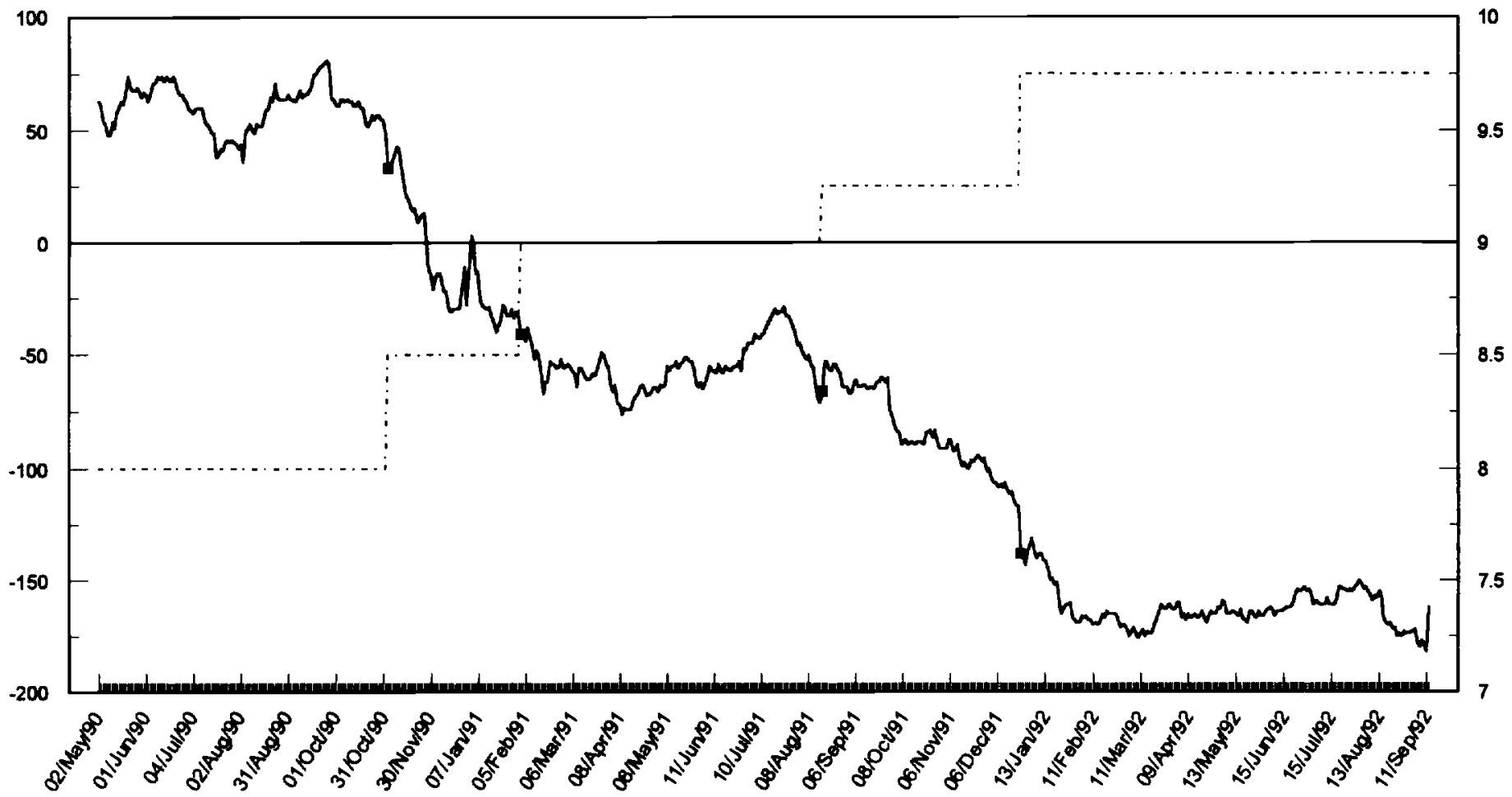

Spread Tightening Lombard rate

\section{b. US: 10-Year minus 3-Month Treasury Spread and the Target Federal Funds}

spread in basis points

Target Fed Funds rate

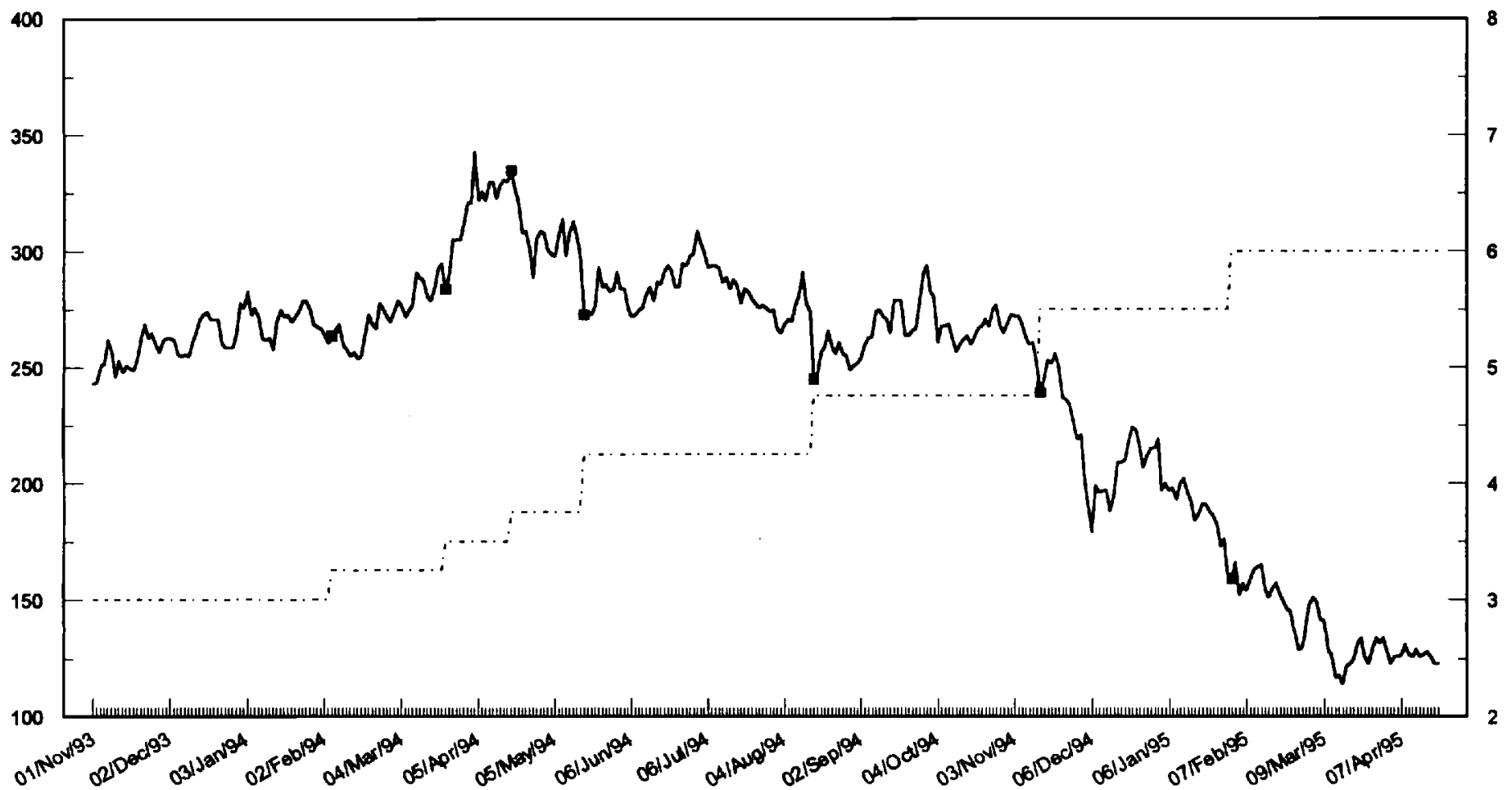


CHART 2

Probit Analysis of Recessions with Term Structure Spread In-Sample, Quarterly Data

France

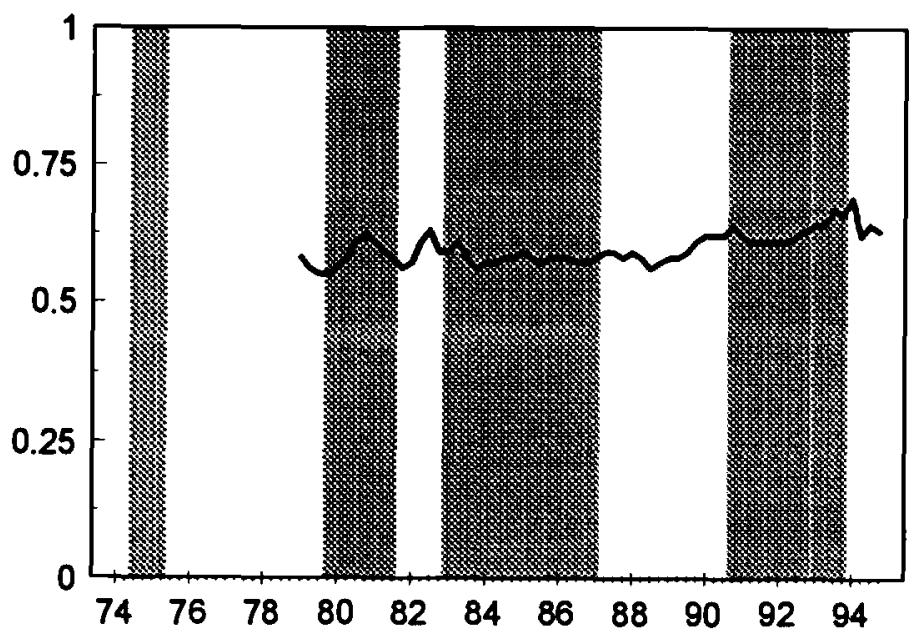

Italy

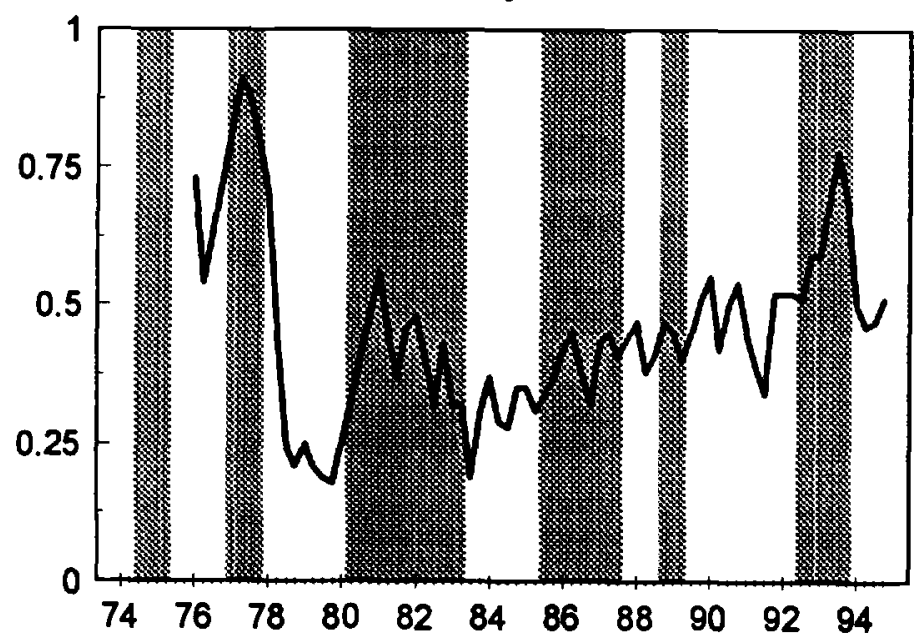

Germany

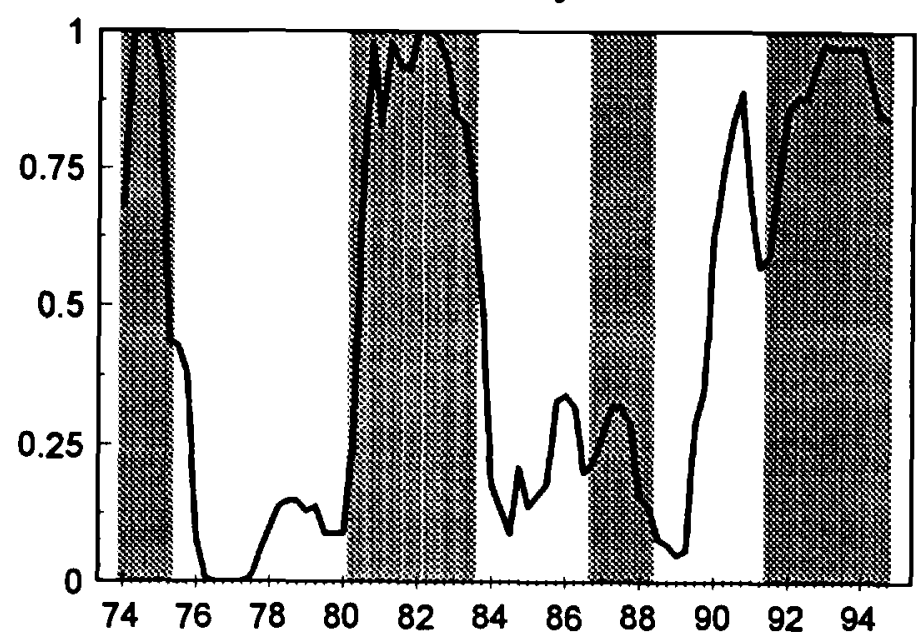

United Kingdom

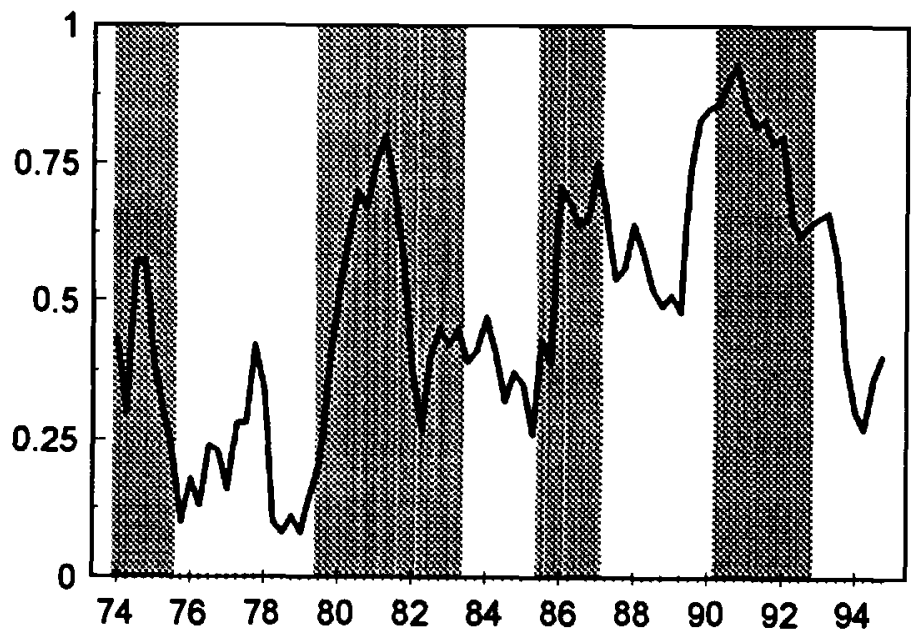

United States

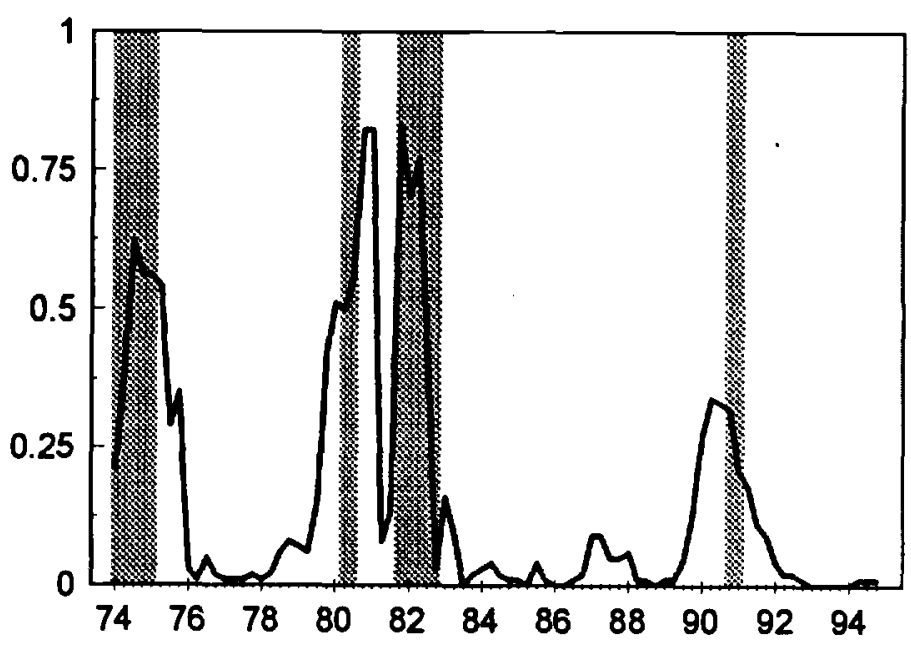




\section{Probability of US Recession Predicted by Treasury Spread}

Out-of-Sample, 4 Quarters Ahead

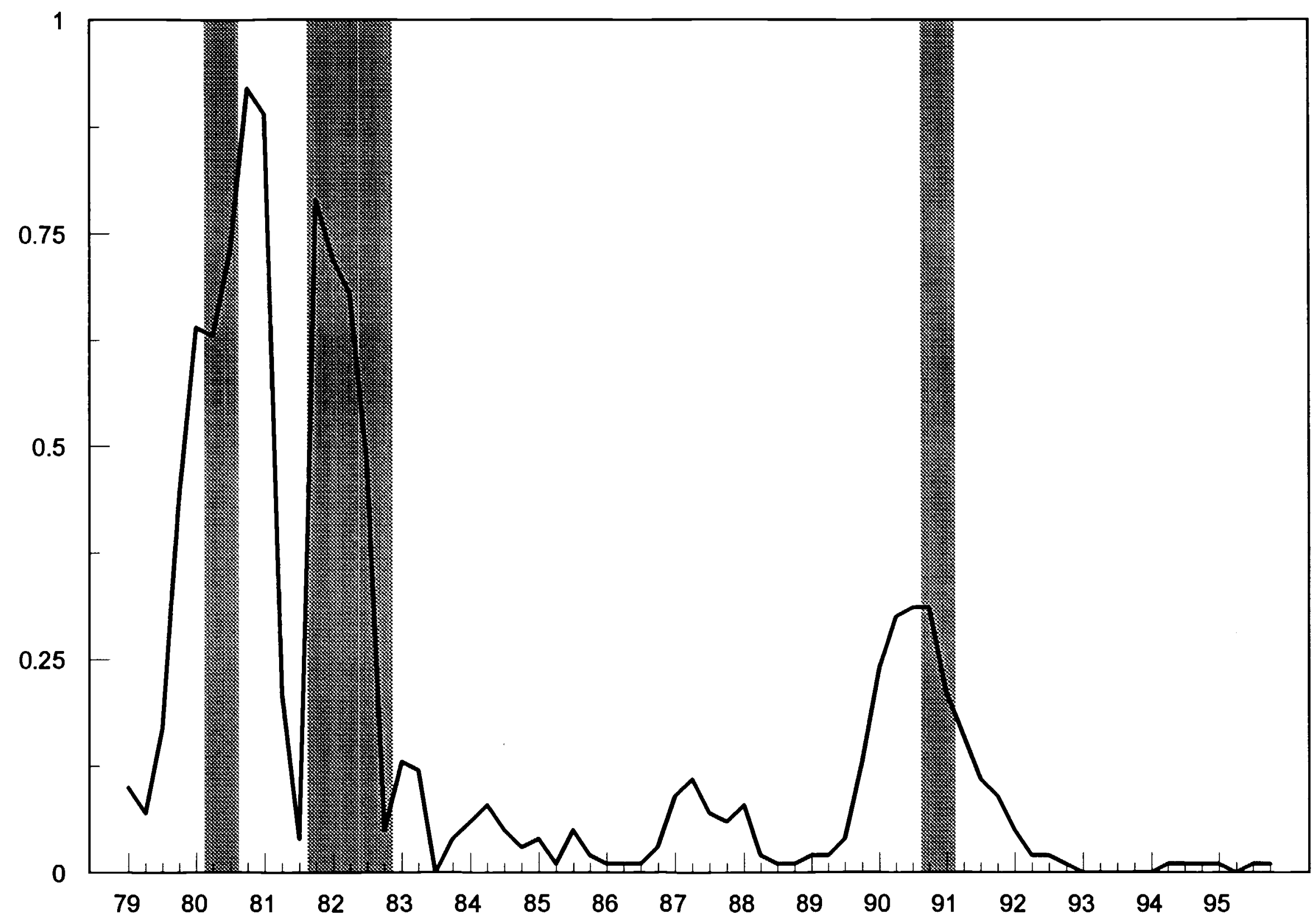

